\title{
Highly Dense and Novel Proton Conducting Materials for SOFC Electrolyte
}

Shahzad Hossain ${ }^{\mathrm{a}, \mathrm{b}, \mathrm{c}^{*}}$, Abdalla M. Abdalla ${ }^{\mathrm{a}, \mathrm{c}, \mathrm{d}}$, Juliana H. Zaini ${ }^{\mathrm{a}}$, Cristian D. Savaniu ${ }^{\mathrm{c}}$, John T. S. Irvine $^{\mathrm{c}}$, Abul K. Azad ${ }^{\mathrm{a}^{*}}$

${ }^{a}$ Faculty of Integrated Technologies, Universiti Brunei Darussalam, Jalan Tungku Link, Gadong, BE 1410, Brunei Darussalam

${ }^{b}$ Institute of Nuclear Science and Technology, Bangladesh Atomic Energy Commission, GPO Box No. 3787, Dhaka 1000, Bangladesh

${ }^{c}$ Center for Advanced Materials, School of Chemistry, University of St Andrews, Fife KY16 9ST, Scotland, UK

${ }^{d}$ Department of Mechanical Engineering, Faculty of Engineering, Suez Canal University, Ismailia 41522, Egypt

*Corresponding authors: shahzad_baec@yahoo.com and abul.azad@ubd.edu.bn

\begin{abstract}
Highly dense proton conducting materials of BCZYSZn $\left(\mathrm{BaCe}_{0.8-\mathrm{x}} \mathrm{Zr}_{\mathrm{x}} \mathrm{Y}_{0.15} \mathrm{Sm}_{0.05} \mathrm{O}_{3-\delta} \quad(\mathrm{x}=0.15\right.$, 0.20) with 4 wt.\% $\mathrm{ZnO}$ as sintering additive), to be used as an intermediate temperature solid oxide fuel cells (IT-SOFCs) electrolyte, have been processed by the conventional solid state reaction method. The crystalline phase, microstructure, electrical properties, cell performance and chemical stability of the materials have been investigated. The ionic conductivity of BCZYSZn $3(x=0.20)$ material has been measured to be $\sim 2.56 \times 10^{-3} \mathrm{~S} \mathrm{~cm}^{-1}$ and $\sim 8.32 \times 10^{-3} \mathrm{~S}$ $\mathrm{cm}^{-1}$ at $600{ }^{\circ} \mathrm{C}$ and $850{ }^{\circ} \mathrm{C}$, respectively in wet $5 \% \mathrm{H}_{2}$ in $\mathrm{Ar}$ atmosphere. Microstructural characterizations of the zinc containing materials (BCZYSZn) show the formation of highly dense morphology with very large grains. The chemical stability test of BCZYSZn in pure $\mathrm{CO}_{2}$
\end{abstract}


shows that the material is very stable up to $1000{ }^{\circ} \mathrm{C}$. The maximum power density for the BCZYSZn 3 electrolyte cell is found to be $0.42 \mathrm{~W} / \mathrm{cm}^{2}$ at $700{ }^{\circ} \mathrm{C}$ under the testing atmosphere. The performed characterizations reveal that these are suitable proton-conducting candidate materials for efficient electrochemical devices.

Keywords: perovskite; SOFC; proton conductor; electrolyte; impedance spectroscopy; power density.

\section{Introduction}

Due to high efficiency (up to 60\%), fuel flexibility and low pollution, solid oxide fuel cells (SOFCs) are considered promising alternative sources of energy production. They have major impact in solving the global energy demand. IT-SOFCs have attracted great attention because of their low temperature operation, potential long term stability, environmental friendliness and economic affordability for many applications (including stationary and automotive) [1-6]. The operation temperature range of oxide ion conducting SOFC is $800-1000{ }^{\circ} \mathrm{C}$ which is quite high and dictated by the choice of electrolyte material (oxide-ion conductors) such as Yttria-Stabilized Zirconia (YSZ), put numerous challenges like high cost and long-term stability issues [7]. While the state of the art SOFC electrolyte for high operating temperatures $\left(800-1000{ }^{\circ} \mathrm{C}\right)$ is $\mathrm{YSZ}$, for intermediate temperatures doped ceria appears to be used for fuel-cell operation below $600{ }^{\circ} \mathrm{C}$ [8]. Some significant issues still remain with doped ceria including residual electronic conductivity and insufficient mechanical integrity under fuel-cell operating conditions.

Searching for a new solid oxide electrolyte which operates at low-temperature is still a major challenge for the SOFCs community. To overcome the high operation temperature issues, there is growing interest in proton conducting electrolyte materials for SOFCs which can operate in 
intermediate temperature $\left(400-700{ }^{\circ} \mathrm{C}\right)$ range. Proton conductors can operate lower temperature due to lower activation energy required for conduction $[3,7]$. Great benefits that results from its employment include cheaper interconnect materials, easier and more reliable sealing, shorter start-up and shut-down time, less chances of materials and performance degradation. Additionally, as water form at the cathode side of an SOFC, hence fuel dilution can be avoid which results in advanced fuel utilization efficiency and higher OCV values [3,9].

Doped barium cerates $\left(\mathrm{BaCeO}_{3}\right)$ and zirconates $\left(\mathrm{BaZrO}_{3}\right)$ are extensively investigated in the literatures [10-16]. These are perovskite $\left(\mathrm{ABO}_{3}\right)$ type oxides which showing good proton conduction. Doped barium cerate, possesses high proton conductivity in the intermediate temperature range especially with 15 or $20 \mathrm{~mol} \%$ of Y; aliovalent co-doped B-site shows even better proton conductivity than $\mathrm{Y}$-doped $\mathrm{BaCeO}_{3}[17-20]$. However, the poor to carbonation (in $\mathrm{CO}_{2}$ containing atmospheres) as well as the instability in water vapors (atmospheres containing stream, $\mathrm{H}_{2} \mathrm{O}$ ) are major challenges for practical applications. On the contrary, Y-doped $\mathrm{BaZrO}_{3}$ e.g., $\mathrm{BaZr}_{0.8} \mathrm{Y}_{0.2} \mathrm{O}_{3-\delta}$, possesses very high chemical stability in $\mathrm{CO}_{2}$ and stream containing atmospheres due to high covalence of the $\mathrm{Zr}-\mathrm{O}$ bond $[7,15,21]$. However, though it has higher symmetry (cubic) as compared to cerates (orthorhombic), it still shows lower ionic conductivity than the cerates due to high grain boundary resistance, limiting its practical applications [22]. It has also an inconsistent variation in the reported conductivity values in the literature, as it depends very much on the synthesis procedure, thermal treatment, etc. The typical sintering temperature of cerates is generally $\sim 1700{ }^{\circ} \mathrm{C}$ which is also very high and makes the electrode supported cells development quite difficult [7].

The solid solutions between $\mathrm{BaCeO}_{3}$ and $\mathrm{BaZrO}_{3}$ has been suggested to find a balance between ionic conductivity and chemical stability [22-30]. To date, $\mathrm{Ba}\left(\mathrm{Zr}_{0.1} \mathrm{Ce}_{0.7} \mathrm{Y}_{0.2}\right) \mathrm{O}_{3-\delta}(\mathrm{BZCY})$ is the 
most widely used proton conducting electrolyte material to possess the high chemical stability as well as high ionic conductivity of $9.0 \times 10^{-3} \mathrm{~S} \mathrm{~cm}^{-1}$ at $500{ }^{\circ} \mathrm{C}$ and there was no evidence [24] of any carbonation or change in structure after exposing it to an atmosphere containing $2 \% \mathrm{CO}_{2}$ and $15 \% \mathrm{H}_{2} \mathrm{O}$ at $500{ }^{\circ} \mathrm{C}$ for one week [28]. But later it has been reported that BZCY shown instability when it was exposed in $3 \% \mathrm{CO}_{2}$ (balanced with air) at $600{ }^{\circ} \mathrm{C}$ for $24 \mathrm{~h}$ and diffraction peaks corresponding to $\mathrm{BaCO}_{3}$ and $\mathrm{CeO}_{2}$ were observed in XRD [29]. Additionally, aliovalent $\mathrm{Y}$ and $\mathrm{Yb}$ co-doped BCZY showed better performance than BZCY and higher ionic conductivity of $14 \times 10^{-3} \mathrm{~S} \mathrm{~cm}^{-1}$ at $500{ }^{\circ} \mathrm{C}[30,31]$. However, though initially $\mathrm{BaZr}_{0.1} \mathrm{Ce}_{0.7} \mathrm{Y}_{0.2} \mathrm{Yb}_{0.1} \mathrm{O}_{3-\delta}$ (BZCYYb) was reported to be stable in $\mathrm{CO}_{2}$ atmospheres, later it was found to be unstable when heated up to $800{ }^{\circ} \mathrm{C}$ in $\mathrm{CO}_{2} / \mathrm{N}_{2}$ (1:2 ratio) atmosphere [32].

The higher doping of zirconia always improve the chemical stability of $\mathrm{BaCeO}_{3}-\mathrm{BaZrO}_{3}$ solid solutions but this causes a drop in ionic conductivity as well as in sintering temperature. While investigating $\mathrm{Ba}\left(\mathrm{Ce}_{0.8-\mathrm{x}} \mathrm{Zr}_{\mathrm{x}}\right) \mathrm{Y}_{0.2} \mathrm{O}_{3-\delta}$ system, Fabbri et al. found carbonation even for $\mathrm{x}=0.5$ i.e., $\mathrm{BaCe}_{0.3} \mathrm{Zr}_{0.5} \mathrm{Y}_{0.2} \mathrm{O}_{3-\delta}$ after exposure to $\mathrm{CO}_{2}$ at $900{ }^{\circ} \mathrm{C}$ for $3 \mathrm{~h}$ [36]. After sintering at $1600{ }^{\circ} \mathrm{C}$ for $8 \mathrm{~h}$, the relative density was $<90 \%$. The searching for a chemically stable electrolyte materials was continuous and a novel composition $\mathrm{Ba}_{0.5} \mathrm{Sr}_{0.5} \mathrm{Ce}_{0.6} \mathrm{Zr}_{0.2} \mathrm{Gd}_{0.1} \mathrm{Y}_{0.1} \mathrm{O}_{3-\delta}$ (BSCZGY) with 50 mol\% Sr doping at the A site and $\mathrm{Y}, \mathrm{Gd}$ co-doping at the $\mathrm{B}$ site showed high stability in $\mathrm{CO}_{2}$ and $\mathrm{H}_{2} \mathrm{O}$ containing atmospheres [37]. There was no evidence of carbonation when kept in flowing pure $\mathrm{CO}_{2}$ at $800{ }^{\circ} \mathrm{C}$ for $24 \mathrm{~h}$ and conductivity of $4 \times 10^{-3} \mathrm{~S} \mathrm{~cm}^{-1}$ at $600{ }^{\circ} \mathrm{C}$ was measured, which is good enough for practical applications [37]. It showed a relative density of $\sim 95 \%$ after firing at $1450{ }^{\circ} \mathrm{C}$ as well as better densification when processed via solid state reaction method; while for BZCY and BZCYYb, a sintering temperature $1550{ }^{\circ} \mathrm{C}$ was required for getting a densification > $90 \%$ when processed by the same (solid state reaction) method [31,33]. 
Among the perovskite oxides, doped barium cerates exhibit mixed oxide and proton ion conductivity [38] upon exposure to stream atmospheres. Proton conductivity can be significantly improved by doping various rare earth ions such as $\mathrm{Y}, \mathrm{Yb}, \mathrm{Eu}, \mathrm{Gd}, \mathrm{Nd}$, etc or using $\mathrm{Sr}$ [39-41]. However, it is difficult to get high density of doped barium cerate/zirconate materials at a sintering temperature below $1400{ }^{\circ} \mathrm{C}$. Getting theoretical density above $90 \%$ of the material we need to sinter at high temperature (above $1400{ }^{\circ} \mathrm{C}$ ) where Ba could evaporate to a certain degree $[42,43]$. To decrease the sintering temperature of ceramics materials, applying a sintering aid is one of the most effective ways [44-47]. In the previous years, to improve the sinterability of ceramic proton conductors, researchers have tried with different additives. The effect of $\mathrm{MO}_{\mathrm{x}}$ metal oxides (where $\mathrm{M}=\mathrm{Ti}, \mathrm{Fe}, \mathrm{Co}, \mathrm{Ni}, \mathrm{Cu}, \mathrm{Zn}$ ) on the densification behavior found that the addition of small amounts of these metal oxides could lower the sintering temperature by 150$250{ }^{\circ} \mathrm{C}$ [46]. Further study showed that the $\mathrm{Cu}$ and $\mathrm{Zn}$ containing materials have significantly higher conductivity than the others in both moistened air and humidified hydrogen atmospheres. However, adding of $\mathrm{CuO}$ led to the formation of $\mathrm{a}^{\mathrm{Ba}} 2 \mathrm{YCu}_{3} \mathrm{O}_{\mathrm{x}}$ impurity phase [48]. On the other hand, under a reduced atmosphere the decrease of $\mathrm{CuO}$ to metallic copper is a large anxiety in practical fuel cell applications. Therefore, as a sintering aid $\mathrm{ZnO}$ in doped $\mathrm{BaCeO}_{3}-\mathrm{BaZrO}_{3}$, is the most encouraging metallic oxide. Formerly, the sintering behavior of proton conductors with $\mathrm{ZnO}$ as a sintering aid was investigated by many researchers [46,48-52]. These researchers usually examined the sintering behavior of thick pellets [46,48,50-52] but applying such electrolytes in real fuel cell fabrication was rare.

In order to solve the density and high sintering temperature issues, $\mathrm{Zn}$ was introduced into $\mathrm{Y}$ and $\mathrm{Zr}$ doped $\mathrm{BaCeO}_{3}$ [48][50]. In 2005, Balibo and Haile first reported that $\mathrm{ZnO}$ is an excellent sintering aid for yttrium-doped $\mathrm{BaZrO}_{3}$, lowering the densification temperature from $1700{ }^{\circ} \mathrm{C}$ to 
$1300{ }^{\circ} \mathrm{C}$ [48]. In 2006, Tao and Irvine found that the introduction of small amount of $\mathrm{Zn}^{2+}$ for $\mathrm{Y}^{3+}$ at the B-site into the perovskite structure allows a reduction in high sintering temperatures and a notable progress in the stability, relative density and conductivity [50]. Slodczyk and Sharp showed that Zinc doped Barium Cerium Zirconium Yttrium oxide has been offering the benefits of both stability and elevated proton conductivity [53] as potential high performance proton conductor. Another group reported [39] by co-doping of $\mathrm{Zr}$ and $\mathrm{Zn}$ in the lattice displayed the stable proton-conducting electrolyte $\mathrm{BaCe}_{0.5} \mathrm{Zr}_{0.3} \mathrm{Y}_{0.16} \mathrm{Zn}_{0.04} \mathrm{O}_{3-\delta}$, sintered at lower temperature which was dense and showed the enhanced chemical stability. Iwahara reported that these oxides also exhibit mixed proton and oxide ion conductivity upon exposure to humid atmosphere [40]. Recently, our group have proved that Zn doped Barium Cerium Zirconium Yttrium Oxide (BCZYZn) offers high proton conductivity and high stability as being electrolyte for proton conducting SOFCs $[47,54]$.

As the physical and electrochemical property of materials depends on the composition, we worked on other compositions with $\mathrm{Zn}$-doping. The $\mathrm{Zn}$ doping not only lowered the sintering temperature, but also increased the stability of $\mathrm{BaCeO}_{3}$-based materials. Considering the issues of low density and stability of various metallic doped $\mathrm{BaCeO}_{3}$, we have motivated to the present research to doped samarium, yttrium, zirconium together at the B site as the compositions of $\mathrm{BaCe}_{0.8-\mathrm{x}} \mathrm{Zr}_{\mathrm{x}} \mathrm{Y}_{0.15} \mathrm{Sm}_{0.05} \mathrm{O}_{3-\delta}(\mathrm{x}=0.15,0.20)$ with 4 wt. $\% \mathrm{ZnO}$ as sintering additive, promising and novel potential electrolyte material, These two new compositions were prepared and, materials structures, properties, morphology, stability and performance were investigated.

\section{Experimental}

\subsection{Preparation of the samples}


The perovskite samples of $\mathrm{BaCe}_{0.8-\mathrm{x}} \mathrm{Zr}_{\mathrm{x}} \mathrm{Y}_{0.15} \mathrm{Sm}_{0.05} \mathrm{O}_{3-\delta}(\mathrm{x}=0.15,0.20$, named as $\mathrm{BCZYS} 2$ and BCZYS 3) sintered in air at $1500{ }^{\circ} \mathrm{C}$ for 12 hours inside a muffle furnace. The materials were processed by the conventional solid state reaction method using the chemicals supplied from the company Sigma Aldrich. Initially, powders of $\mathrm{BaCO}_{3}, \mathrm{CeO}_{2}, \mathrm{ZrO}_{2}, \mathrm{Y}_{2} \mathrm{O}_{3}$ and $\mathrm{Sm}_{2} \mathrm{O}_{3}$ (purity of all chemicals were stated as more than $99.95 \%$ ) were used in precise stoichiometric ratios. The powders were preheated at $200{ }^{\circ} \mathrm{C}$ for 3 hours inside a muffle furnace and then weighed quickly to prevent re-carbonation, individually using a precise digital micro balance and then thoroughly mixed in an agate mortar with small amount of ethanol. After that the samples were ball milled and mixed intimately with appropriate amount of ethanol using a ball-mill machine for 4 hours. Then the mixture was naturally dried overnight inside a fume hood and then heated on a magnetic hotplate at a temperature of $80{ }^{\circ} \mathrm{C}$ for 2 hours of each composition. The powders were then heated at $900{ }^{\circ} \mathrm{C}$ for 14 hours inside the muffle furnace in an alumina crucible with a heating and cooling rate of $5^{\circ} \mathrm{C}$ per min for calcination. Then the calcined samples were ground in a mortar pestle for half an hour of each and then mixed with a small amount of binder $\left(\right.$ Decoflux $^{\mathrm{TM}}$ ) and ground again for about 30 minutes before pressed into the pellets of $2 \mathrm{~g}$ of 13 mm diameter under the hydraulic press of 3 ton pressure. The pellets were heated at $1200{ }^{\circ} \mathrm{C}$ for 12 hours inside the furnace in air. The heated samples were re-ground using a small amount of binder and pressed into pellets again. The pellets of BCZYS were heated at a final temperature of $1500{ }^{\circ} \mathrm{C}$ for $12 \mathrm{~h}$. For more complete reaction, the grinding and pelleting were repeated and were done two intermediate heating at $1350{ }^{\circ} \mathrm{C}$ and $1450{ }^{\circ} \mathrm{C}$ for 12 and 10 hours respectively. After sintered at $1500{ }^{\circ} \mathrm{C}$ for 12 hours of BCZYS, 4 wt. \% ZnO was used with BCZYS (as sintering additive) to prepared BCZYSZn. Then the powders (BCZYS plus 4 wt. \% ZnO) were mixed with ethanol, grinded for 1 hour of each and then heated at $1350{ }^{\circ} \mathrm{C}$ for 14 hours to improve the 
densification. After the confirmation of the pure phase and enough density of BCZYSZn (obtained by sintered powder of BCZYS plus $4 \%$ wt. $\mathrm{ZnO}$ powder), the larger amount of BCZYSZn (two samples named as BCZYSZn 2 and BCZYSZn 3) were prepared with the initials powers and pure $\mathrm{ZnO}$ by the same process and were finally sintered at $1400{ }^{\circ} \mathrm{C}$ for 10 hours in air for the further characterizations.

\subsection{Characterizations of the materials}

The PANalytical Empyrean Diffractometer was used to analyze the phase of the calcined and sintered samples of BCZYS and BCZYSZn. The high resolution XRD patterns of the sintered samples were analyzed by the Rietveld method using the Fullprof software. For microstructural studies, the powders were pressed into pellets by uniaxial press, sintered before using in a JEOL 5600 SEM instrument. A dc conductivity jig of 4-terminals (van der Pauw, an in house built dc conductivity jig) was used to measure the dc conductivities of the materials. The dc conductivity pellets (rectangular bars of BCZYS 2 and BCZYS 3) were prepared by the sintered BCZYS powders. The powders (BCZYS) were mixed with ethanol, ground, dried and then added little amount of deionized water and Decoflux and then rectangular pellets were prepared. Four small gold wires were connected to the each bar with the help of gold paste for the four probes connections, dried in the oven and then heated at $700{ }^{\circ} \mathrm{C}$ for $30 \mathrm{~min}$. Electrical conductivity was measured from 200 to $850{ }^{\circ} \mathrm{C}$ with the interval of $50{ }^{\circ} \mathrm{C}$ with the heating rate of $3{ }^{\circ} \mathrm{C} / \mathrm{min}$ in wet $5 \% \mathrm{H}_{2}$. The ionic conductivities of the samples BCZYSZn 2 and BCZYSZn 3 were measured using a Solartron impedance spectrometer with frequency response analyzer. The $13 \mathrm{~mm}$ dia, $\sim 1.3 \mathrm{~mm}$ thick pellets of BCZYSZn were well sintered, polished, and gold painted, dried in the

oven and then heated at $700{ }^{\circ} \mathrm{C}$ for $30 \mathrm{~min}$. The current of amplitude of $50 \mathrm{~mA}$ was applied to 
measure the impedance from 200 to $850{ }^{\circ} \mathrm{C}$ with the interval of $50{ }^{\circ} \mathrm{C}$ and heating rate of 3 ${ }^{\circ} \mathrm{C} / \mathrm{min}$ in air and wet $5 \% \mathrm{H}_{2}$ in the frequency range of $1 \mathrm{MHz}-10 \mathrm{mHz}$. The cell performance was studied with a single cell of Ni-BCZYS $\mid$ BCZYSZn $\mid$ LSCM. The anode and cathode was prepared with the powders of $\mathrm{NiO}$, BCZYS and LSCM $\left(\left(\mathrm{La}_{0.75} \mathrm{Sr}_{0.25}\right)_{0.97} \mathrm{Cr}_{0.5} \mathrm{Mn}_{0.5} \mathrm{O}_{3 \pm \delta}\right)$. Initially the anode substrates were prepared with $\mathrm{NiO}$ and BCZYS 3 (weight, 1:1) and, then BCZYSZn 3 electrolyte and LSCM cathode were screen printed on the anode substrate one after another. Pt paste was used at the anode and cathode sides as current collector. The single cell was fixed on the testing jig with Ceramabond from Aremco Scientific Co. and the measurements were done at $850{ }^{\circ} \mathrm{C}$ to $600{ }^{\circ} \mathrm{C}$ with an interval of $50{ }^{\circ} \mathrm{C}$ using air at cathode side and $5 \%\left(\mathrm{H}_{2} / \mathrm{Ar}\right)$ at anode side with the flow rate of $100 \mathrm{ml} / \mathrm{s}$. Thermogravimetric analysis (TGA) was performed to study the chemical stability of the materials. TGA data were collected from the powder samples in $\mathrm{CO}_{2}$ atmosphere with a heating rate of $5{ }^{\circ} \mathrm{C} / \mathrm{min}$ from 30 to $1000{ }^{\circ} \mathrm{C}$. The samples were kept isothermally for $30 \mathrm{~min}$ at the final temperature and then cooled down to $50{ }^{\circ} \mathrm{C}$ at the same rate with the $\mathrm{CO}_{2}$ flow rate of $50 \mathrm{ml} / \mathrm{min}$ for both the carrier and protection. The XRD data were collected on the samples after TGA measurements to check any phase change for the experiments.

\section{Results and discussion}

\subsection{Phase analyses of the samples}

The indexing of XRD data of the compound exhibits the orthorhombic symmetry. The Fullprof software was used for Rietveld refinement which confirms the orthorhombic symmetry with the Pbnm space group. This space group was used in the data refinement process for generating the calculated diffraction profiles to compare with observed profiles after justified with some other 
crystal structures and space groups. Rietveld refinement profile of the XRD data of $\mathrm{BaCe}_{0.65} \mathrm{Zr}_{0.15} \mathrm{Y}_{0.15} \mathrm{Sm}_{0.05} \mathrm{O}_{3-\delta}$ and $\mathrm{BaCe}_{0.6} \mathrm{Zr}_{0.2} \mathrm{Y}_{0.15} \mathrm{Sm}_{0.05} \mathrm{O}_{3-\delta}$ (i.e., BCZYS 2 and BCZYS 3) after sintered at $1500{ }^{\circ} \mathrm{C}$ for $12 \mathrm{~h}$ in air are shown in Fig 1 . Both of the samples confirm the single phase perovskite structure after the Rietveld analyses of the X-ray diffraction patterns.

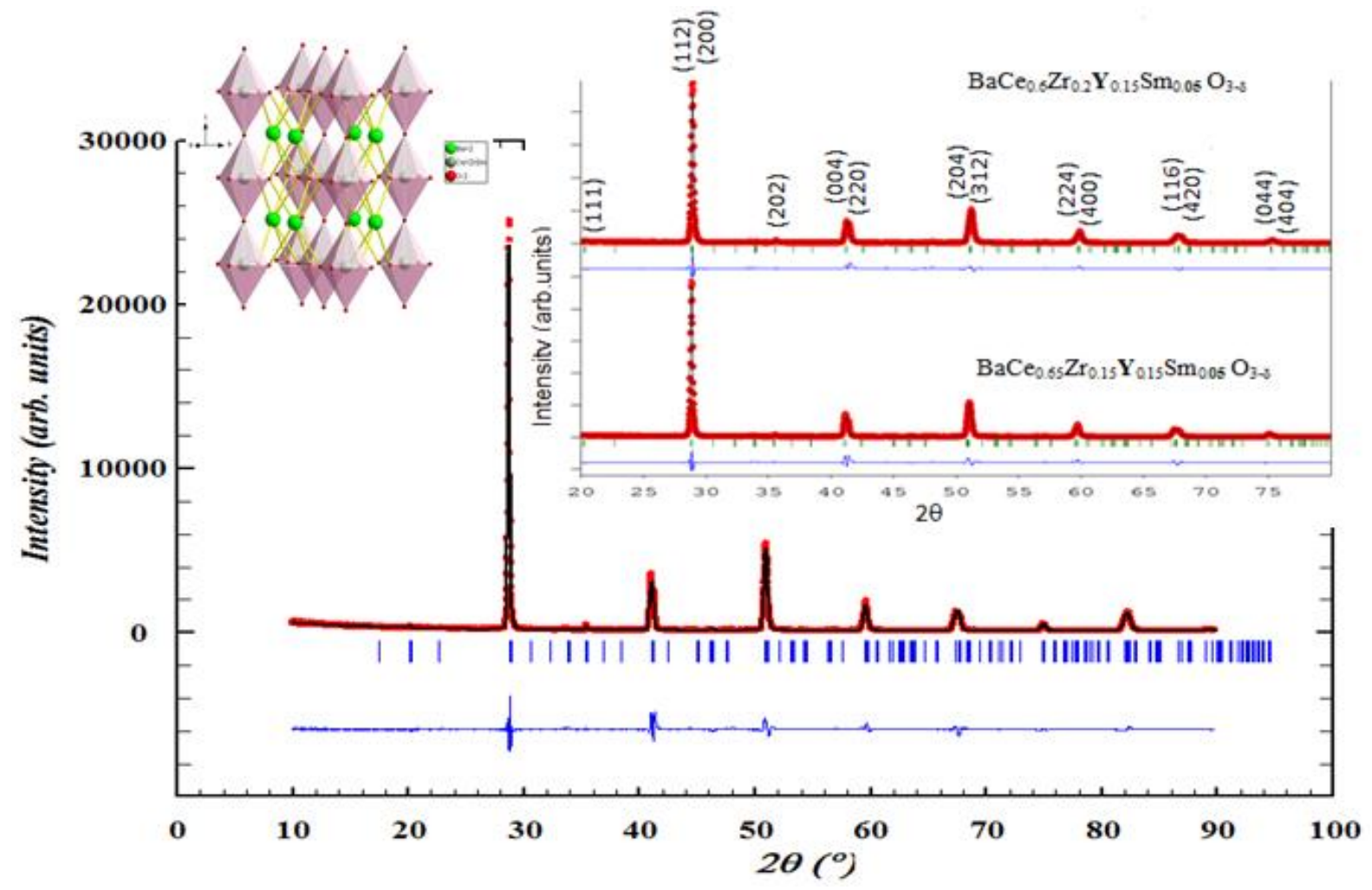

Fig. 1. Rietveld refinement $\mathrm{X}$ - ray diffraction data of as-prepared $\mathrm{BaCe}_{0.65} \mathrm{Zr}_{0.15} \mathrm{Y}_{0.15} \mathrm{Sm}_{0.05} \mathrm{O}_{3-\delta}$ and $\mathrm{BaCe}_{0.6} \mathrm{Zr}_{0.2} \mathrm{Y}_{0.15} \mathrm{Sm}_{0.05} \mathrm{O}_{3-\delta}$ at room temperature. The red dots are observed, black line is calculated and the blue line is the difference pattern (observed minus calculated results), and the vertical lines are the Bragg positions.

The refinement parameters from Rietveld analysis are listed in Table 1. From the refinement results it is found that the lattice parameters decrease with the increasing in zirconium content 
which is due to the smaller ionic radius of zirconium (radius of $\mathrm{Zr}^{4+}=0.72 \AA$, coordination number $(\mathrm{CN})=6$ ) than that of cerium (radius of $\mathrm{Ce}^{4+}=0.87 \AA$ in the same $\mathrm{CN}$ ).

Table 1. Crystallographic parameters of BCZYS from Rietveld analysis of the XRD data.

\begin{tabular}{ccccc}
\hline Chemical compounds & Space Group & $\mathrm{a}(\AA)$ & $\mathrm{b}(\AA)$ & $\mathrm{c}(\AA)$ \\
\hline $\mathrm{BaCe}_{0.65} \mathrm{Zr}_{0.15} \mathrm{Y}_{0.15} \mathrm{Sm}_{0.05} \mathrm{O}_{3-\delta}$ & Pbnm & $6.1693(8)$ & $6.1785(4)$ & $8.7739(2)$ \\
$\mathrm{BaCe}_{0.6} \mathrm{Zr}_{0.2} \mathrm{Y}_{0.15} \mathrm{Sm}_{0.05} \mathrm{O}_{3-\delta}$ & Pbnm & $6.1541(4)$ & $6.1598(4)$ & $8.7297(7)$
\end{tabular}

The samples which contain $4 \mathrm{wt} . \% \mathrm{ZnO}$ as additive i.e., BCZYSZn were sintered at $1400{ }^{\circ} \mathrm{C}$ for 10 hours for XRD characterization and shown the pure phase (X-ray patterns are shown in Fig. 2). The Rietveld refinements of BCZYSZn show that the lattice parameters, atomic positions and temperature factors are similar to non Zn-added (BCZYS) samples.

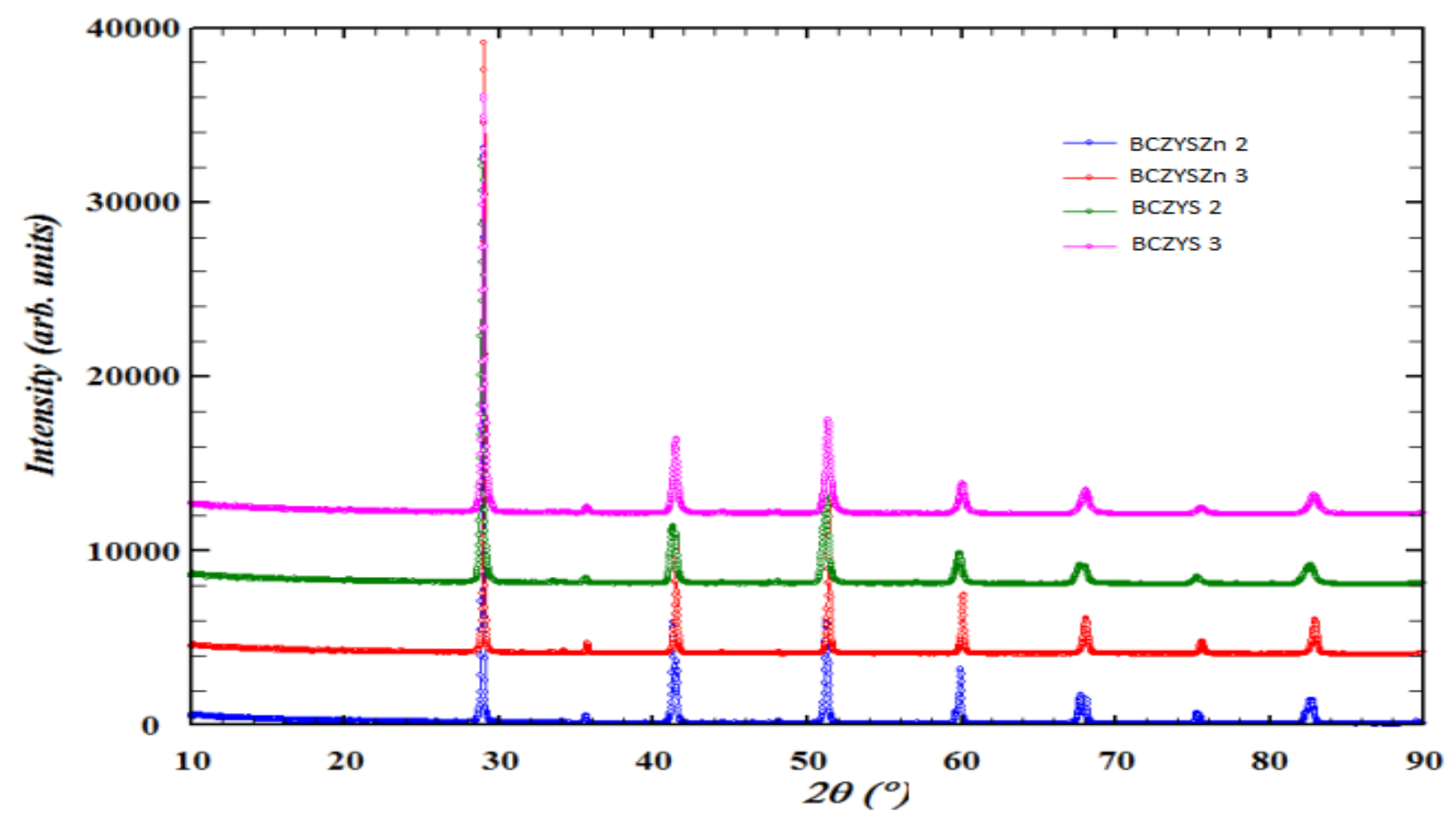

Fig. 2. The $\mathrm{X}$ - ray diffraction patterns of as-prepared BCZYS (sintered at $1500{ }^{\circ} \mathrm{C}$ for $12 \mathrm{~h}$ ) and BCZYSZn (sintered at $1400{ }^{\circ} \mathrm{C}$ for $10 \mathrm{~h}$ ) at room temperature. Samples names are inserted in the 
top right. The peaks of $\mathrm{ZnO}$ added samples (BCZYSZn) show sharper than non-ZnO added samples (BCZYS).

The theoretical densities from the Rietveld refinement of BCZYS 2 and BCZYS 3 were measured to be 6.054 and $6.167 \mathrm{~g} / \mathrm{cm}^{3}$, respectively and the empirical density measured by the Archimedes' principle were $4.044 \mathrm{~g} / \mathrm{cm}^{3}$ and $4.056 \mathrm{~g} / \mathrm{cm}^{3}$, respectively. The percentage of relative density of BCZYS 2 and BCZYS 3 were $66.8 \%$ and $65.76 \%$, respectively. Similarly, the densities of BCZYSZn 2 and BCZYSZn 3 were also measured where the percentage of relative densities were $96.6 \%$ and $98.96 \%$, respectively. The relative densities were increased by $\sim 29.8 \%$ and $33.20 \%$ for addition of $\mathrm{ZnO}$ in BCZYS 2 and BCZYS 3, respectively. So, it is concluded from XRD that addition of $\mathrm{ZnO}$ in BCZYS significantly decreases the sintering temperature and increases the relative densities.

\subsection{Microstructural analysis}

Fig. 3 (a-b) show the SEM images of BCZYS samples obtained after sintered at $1500{ }^{\circ} \mathrm{C}$ for 12 hours. These microstructures were porous which became highly dense after added 4 wt. \% $\mathrm{ZnO}$ as the sintering additive as shown in Fig. 3(c-f).

The SEM micrographs (Fig. 3 (c-f)) of the fracture surfaces of BCZYSZn materials show that the samples sintered at $1350{ }^{\circ} \mathrm{C}$ and $1450{ }^{\circ} \mathrm{C}$ were highly dense without any pores or cracks. The sample BCZYSZn 3 was smoother, free of cracks and the grain was well grown making it highly dense material. The images show that the grains are completely compact and are large which give high density as the requirement of the electrolyte materials. 

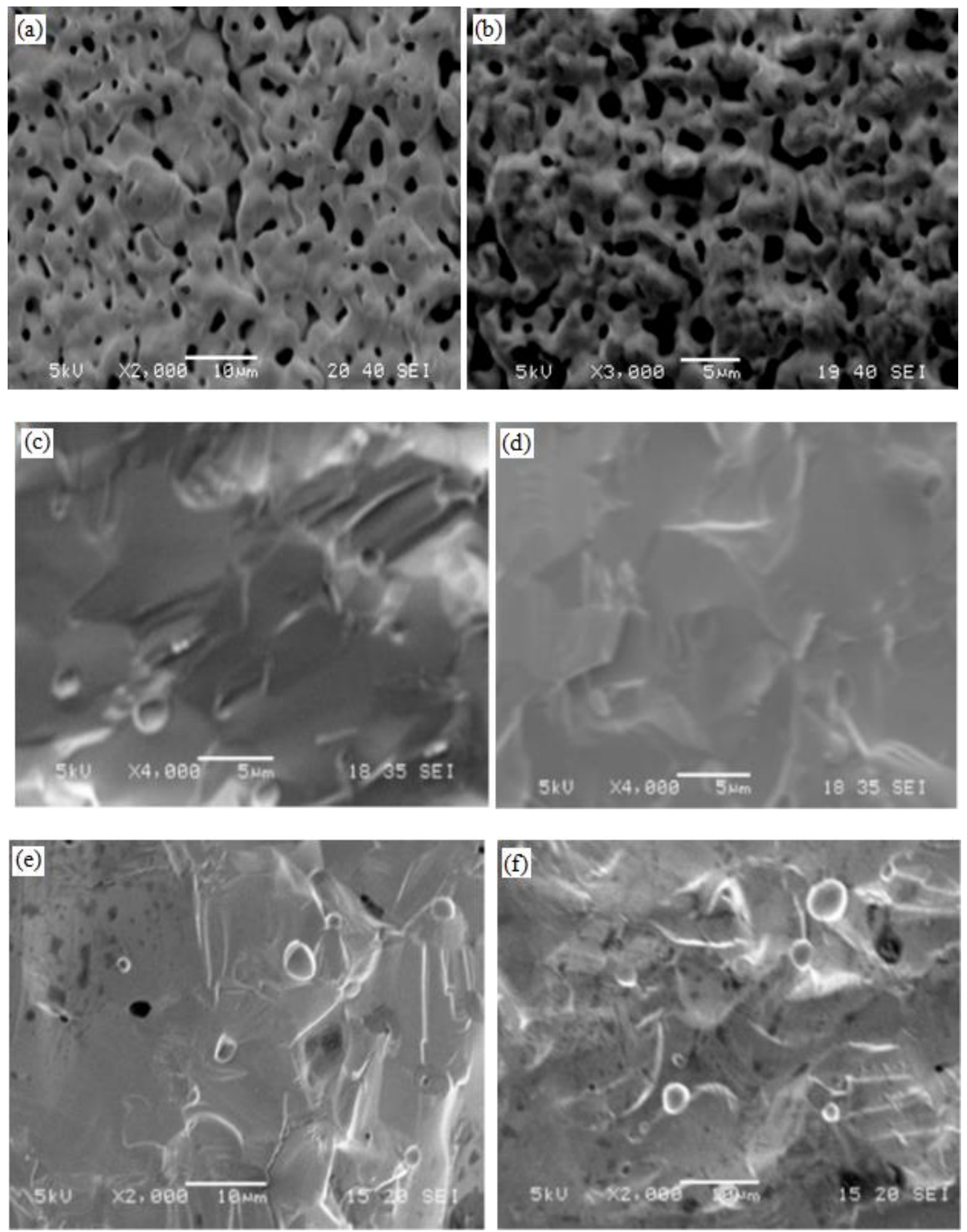
Fig. 3. SEM micrographs of as-prepared (a) BCZYS 2 and (b) BCZYS 3 sintered at $1500{ }^{\circ} \mathrm{C}$ for 12 hours; (c) BCZYSZn 2 and (d) BCZYSZn 3 sintered at $1350{ }^{\circ} \mathrm{C}$ for 14 hours; and (e) BCZYSZn 2 and (f) BCZYSZn 3 sintered at $1400{ }^{\circ} \mathrm{C}$ for 10 hours.

From the SEM images of BCZYSZn 2 and BCZYSZn 3 (Fig. 3 (c-f)) it is clear that the grain sizes are quite large and uniform. Normally, the average grain size for ceria rich compositions are larger than that for $\mathrm{Zr}$ rich compositions [36]. This indicates that the nature of dopant influences the overall grain size distribution. The larger grain size of the sample offers less overall grain boundary resistance, which is beneficial for the total conductivity of the sample. It can be observed from the SEM studies that samarium, yttrium, zirconium doped at the B-site and adding zinc as sintering additive increasing the density quite high and making grain sizes large. The distribution of grain size of the BCZYSZn materials were relatively uniform and sizes (the grain size is $\geq 8 \mu \mathrm{m}$ for sintering temperature of $1350{ }^{\circ} \mathrm{C}$ and the size is more larger for sintering temperature of $1400{ }^{\circ} \mathrm{C}$ ) were larger in comparison with the doped $\mathrm{BaZr}_{0.1} \mathrm{Ce}_{0.7} \mathrm{Y}_{0.1} \mathrm{M}_{0.1} \mathrm{O}_{3-\delta}(\mathrm{M}$ $=\mathrm{Fe}, \mathrm{Ni}, \mathrm{Co}$ and $\mathrm{Yb}$ ) after sintering at $1250{ }^{\circ} \mathrm{C}$ for $24 \mathrm{~h}, 1350{ }^{\circ} \mathrm{C}$ for $24 \mathrm{~h}$ and $1550{ }^{\circ} \mathrm{C}$ for $12 \mathrm{~h}$, respectively [35] and the grains of 2-8 $\mu \mathrm{m}$ range of $\mathrm{BaCe}_{0.5} \mathrm{Zr}_{0.3} \mathrm{Y}_{0.2} \mathrm{O}_{3-\delta}$ which was sintered at $1600{ }^{\circ} \mathrm{C}$ for 8 hours [36]. The grains sizes were larger than the reported grain size for BZCY and BZCYYb which were $5 \mu \mathrm{m}$ and $3 \mu \mathrm{m}$ after sintering at $1400{ }^{\circ} \mathrm{C}$ for $6 \mathrm{~h}$, respectively [55]. Also it is very larger than the grain size of $\mathrm{BaZr}_{0.7} \mathrm{Pr}_{0.1} \mathrm{Y}_{0.2} \mathrm{O}_{3-\delta}$ (BZPY) [56] which was $1.7 \mu \mathrm{m}$ after sintering at $1600{ }^{\circ} \mathrm{C}$ for $8 \mathrm{~h}$ or the grain size of about $1.0 \mu \mathrm{m}$ reported for $\mathrm{BZCYYb}$ which was finally sintered at $1400{ }^{\circ} \mathrm{C}$ for $5 \mathrm{~h}$ [57]. So, adding $\mathrm{ZnO}$ (4 wt. \%) with doped $\mathrm{Sm}, \mathrm{Y}$ and $\mathrm{Zr}$ at Bsite of $\mathrm{BaCeO}_{3}$ was found to be very beneficial not only for good densification but also for grain growth. 
On the top surface of the grains a very few sub-micron crystals were observed in SEM images (in Fig. 3 (c), (e) and (f)). But the elemental distribution of BCZYSZn by using energy dispersive X-ray (EDX) shows that the materials are very close to the provided value (\%EDX) to the calculated value from the formula $(\% \mathrm{~F})$ (see Table 2$)$.

Table 2. Elemental distribution analysis of BCZYSZn by chemical formula and EDX experiment.

\begin{tabular}{|c|c|c|c|c|c|c|c|c|}
\hline \multirow{3}{*}{$\begin{array}{l}\text { Sample } \\
\text { Element }\end{array}$} & \multicolumn{4}{|c|}{ BCZYSZn 2} & \multicolumn{4}{|c|}{ BCZYSZn 3} \\
\hline & \multicolumn{2}{|c|}{ Formula } & \multicolumn{2}{|c|}{ EDX } & \multicolumn{2}{|c|}{ Formula } & \multicolumn{2}{|c|}{ EDX } \\
\hline & Weight & Atomic & Weight & Atomic & Weight & Atomic & Weight & Atomic \\
\hline Symbol & $\%$ & $\%$ & $\%$ & $\%$ & $\%$ & $\%$ & $\%$ & $\%$ \\
\hline $\mathrm{Ba}$ & 50.69 & 48.0 & 50.53 & 47.89 & 51.17 & 48.0 & 51.13 & 47.86 \\
\hline $\mathrm{Ce}$ & 35.02 & 32.5 & 34.98 & 32.57 & 32.63 & 30.0 & 32.62 & 30.08 \\
\hline $\mathrm{Zr}$ & 5.26 & 7.5 & 5.37 & 7.47 & 7.11 & 10.0 & 7.17 & 10.07 \\
\hline $\mathrm{Y}$ & 5.13 & 7.5 & 5.27 & 7.56 & 5.15 & 7.5 & 5.22 & 7.56 \\
\hline $\mathrm{Sm}$ & 2.89 & 2.5 & 2.86 & 2.53 & 2.92 & 2.5 & 2.86 & 2.46 \\
\hline $\mathrm{Zn}$ & 1.01 & 2.0 & 0.99 & 1.98 & 1.02 & 2.0 & 1.00 & 1.97 \\
\hline
\end{tabular}

From the EDX analysis, it is observed that the reporting materials have similar ratio of elements and the grains of the samples are quite large. The presence of any extra phase was also below the detection limit in the electron image (in EDX-SEM analysis) and not any unreacted initial or primary particle was found that did not sinter in this synthesis method (solid state reaction). 


\subsection{Conductivity measurements}

Fig. 4 (a) and (b) show the conductivity evolution for BCZYS sintered at $1500{ }^{\circ} \mathrm{C}$ for 12 hours, measured in humidified $5 \% \mathrm{H}_{2} / \mathrm{Ar}$ on cooling using a four-terminals -van der Pauw method. The BCZYS 2 shows the conductivity value of $2 \times 10^{-3} \mathrm{~S} \mathrm{~cm}^{-1}$ at $600{ }^{\circ} \mathrm{C}$ and $7 \times 10^{-3} \mathrm{~S} \mathrm{~cm}^{-1}$ at $850{ }^{\circ} \mathrm{C}$ and for BCZYS 3 it is found to be $1.7 \times 10^{-3} \mathrm{~S} \mathrm{~cm}^{-1}$ at $600{ }^{\circ} \mathrm{C}$ and $5 \times 10^{-3} \mathrm{~S} \mathrm{~cm}^{-1}$ at $850{ }^{\circ} \mathrm{C}$, respectively. As it can be seen from the graphs, the conductivity increases with the temperature, indicating the presence of p-type conduction, with two changes in slope, around $475{ }^{\circ} \mathrm{C}$ and 700 ${ }^{\circ} \mathrm{C}$, as in this temperature range the conductivity is increasing much slower with the temperature.

(a)

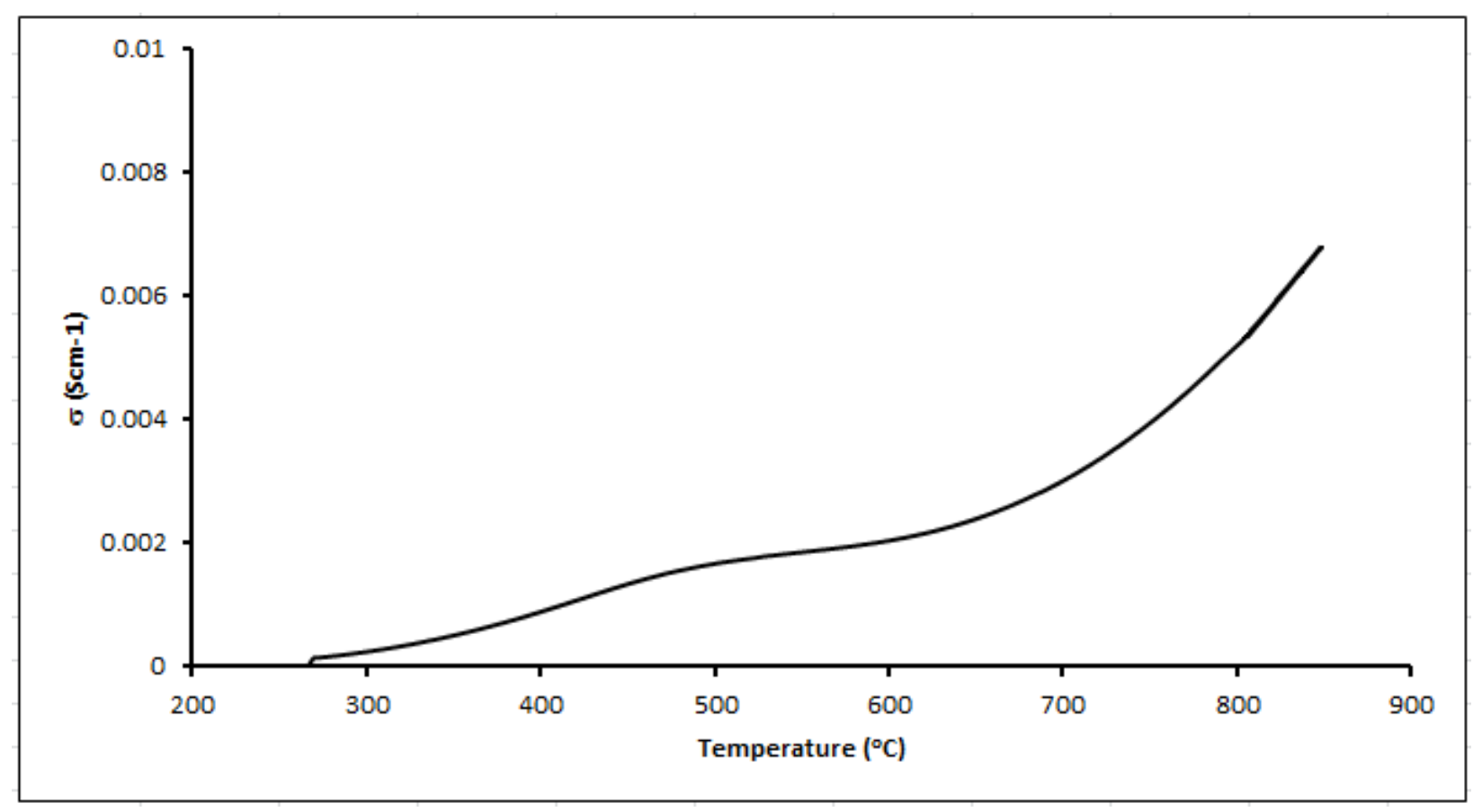

(b) 


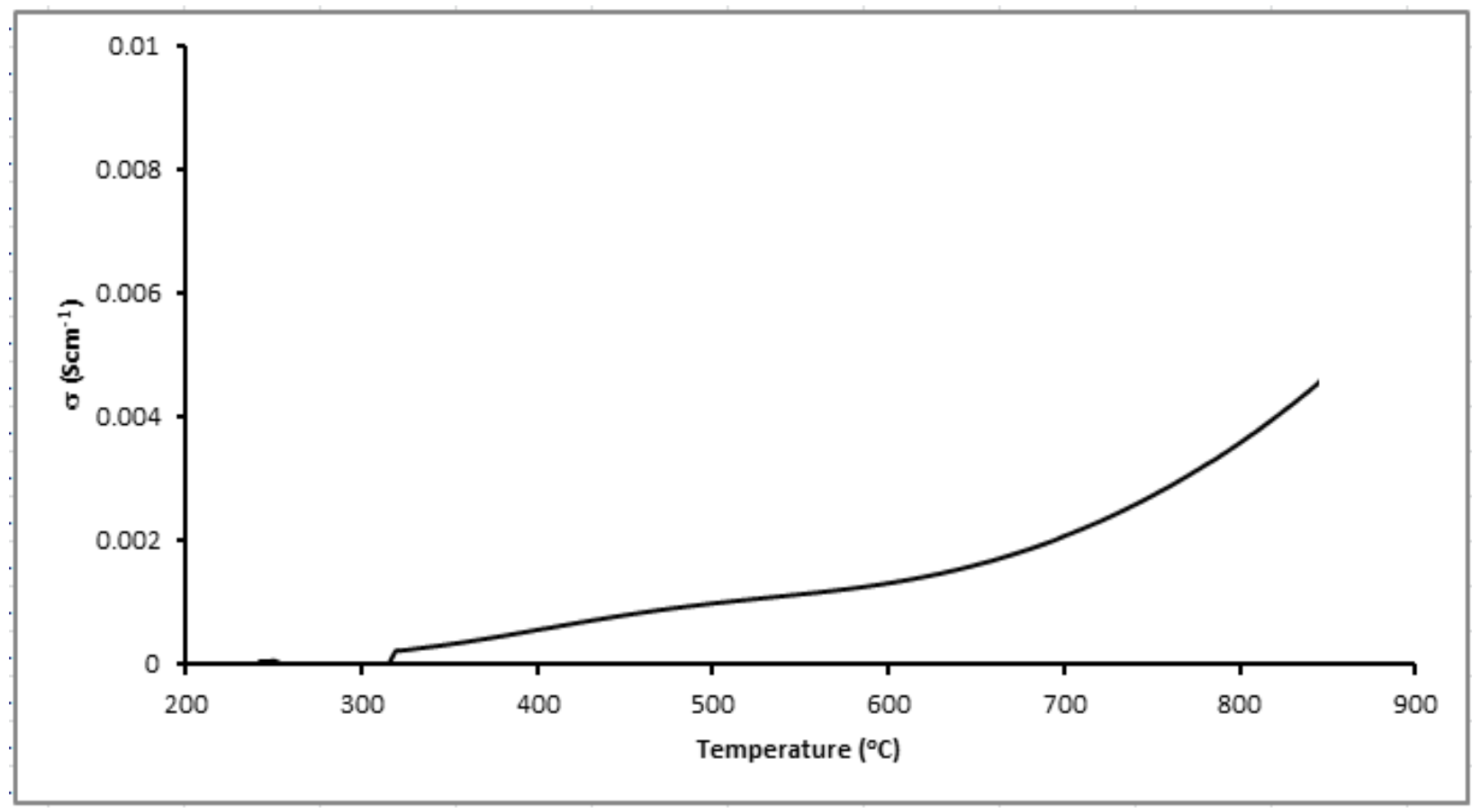

Fig. 4. DC conductivity of (a) BCZYS 2 and (b) BCZYS 3 in wet $5 \% \mathrm{H}_{2} / \mathrm{Ar}$ sintered at $1500{ }^{\circ} \mathrm{C}$.

The range $10^{-2}-10^{-3} \mathrm{~S} \mathrm{~cm}^{-1}$ at $600{ }^{\circ} \mathrm{C}$ temperature, an ionic conductivity is considered suitable for practical applications of proton conducting oxides. In order to disseminate between different responses (grain/grain boundary), ac impedance technique was employed to measure the ionic conductivities of BCZYSZn in air and wet $5 \% \mathrm{H}_{2} / \mathrm{Ar}$ atmospheres are shown in Fig. 5 (a-d). Arrhenius plots are shown in Fig. 6 (a-b). The measured value of ionic conductivity at $600{ }^{\circ} \mathrm{C}$ in wet $5 \% \mathrm{H}_{2}$ is $\sim 1.24 \times 10^{-3} \mathrm{~S} \mathrm{~cm}^{-1}$ and $\sim 2.56 \times 10^{-3} \mathrm{~S} \mathrm{~cm}^{-1}$ for BCZYSZn 2 and BCZYSZn 3 , respectively, higher than those reported for the $\mathrm{Y} / \mathrm{Yb}$ doped compositions [8], [36], [58].

The impedance spectra at $400{ }^{\circ} \mathrm{C}$ consist of 2 responses that can be attributed to the grain boundary response $\left(\mathrm{C} \sim \mathrm{nFcm}^{-1}\right)$ and a dominating electrode response $\left(\mathrm{C} \sim \mu \mathrm{Fcm}{ }^{-1}\right)$ for geometrical capacitance values. At this temperature the grain response of reporting materials is not visible, being assimilated to the high frequency intercept with the $Z^{\prime}$ axis. The Arrhenius plot of conductivity of the BCZYSZn samples in wet $5 \% \mathrm{H}_{2}$ is plotted in Fig. 6 (b). In air atmosphere, 
the total resistivity is dominated by the grain boundary above $700^{\circ} \mathrm{C}$. All total conductivities are higher in wet $5 \% \mathrm{H}_{2}$ than those in air, indicating that the significant improvement in conductivity is due to the absorption of steam resulting in enhanced proton conduction [59].

The conductivities for both samples in air are significantly lower than that of wet $5 \% \mathrm{H}_{2}$ atmosphere, at intermediate temperature, an indication of the proton conductivity existence. The p-type conduction of $\mathrm{Y}$-doped $\mathrm{BaZrO}_{3}$ at higher $\mathrm{pO}_{2}$ is well known [60] and it is reasonable to assume that reporting materials exhibit the similar behavior. Similar behavior was observed for $\mathrm{Ba}_{0.97} \mathrm{Zr}_{0.77} \mathrm{Y}_{0.19} \mathrm{Zn}_{0.04} \mathrm{O}_{3-\delta}$ [51], as the total conductivity of $\mathrm{BaZr}_{0.8} \mathrm{Y}_{0.2} \mathrm{O}_{3-\delta}$ in wet $5 \% \mathrm{H}_{2}$ at 900 ${ }^{\circ} \mathrm{C}$ was $2.02 \times 10^{-4} \mathrm{~S} \mathrm{~cm}^{-1}$ which was twice of that in dry $5 \% \mathrm{H}_{2}$. The total conductivity measurements on $\mathrm{Ba}_{0.97} \mathrm{Zr}_{0.77} \mathrm{Y}_{0.19} \mathrm{Zn}_{0.04} \mathrm{O}_{3-\delta}$ sintered at $1325{ }^{\circ} \mathrm{C}$ at $900{ }^{\circ} \mathrm{C}$ was $1.94 \times 10^{-2} \mathrm{~S} \mathrm{~cm}^{-1}$ which was nearly double that of $\mathrm{BaZr}_{0.8} \mathrm{Y}_{0.2} \mathrm{O}_{3-\delta}$ under the same condition.

(a)
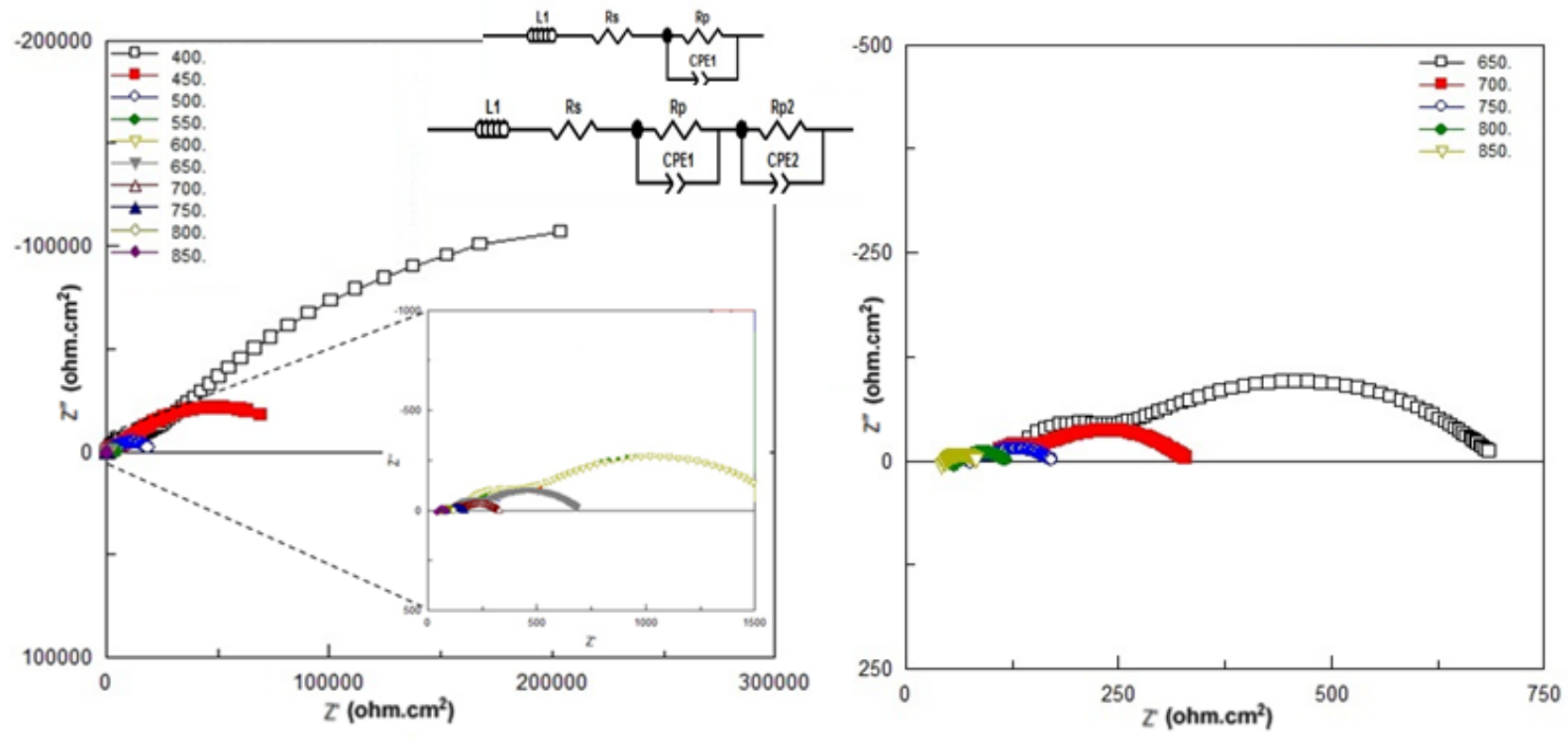

(b) 

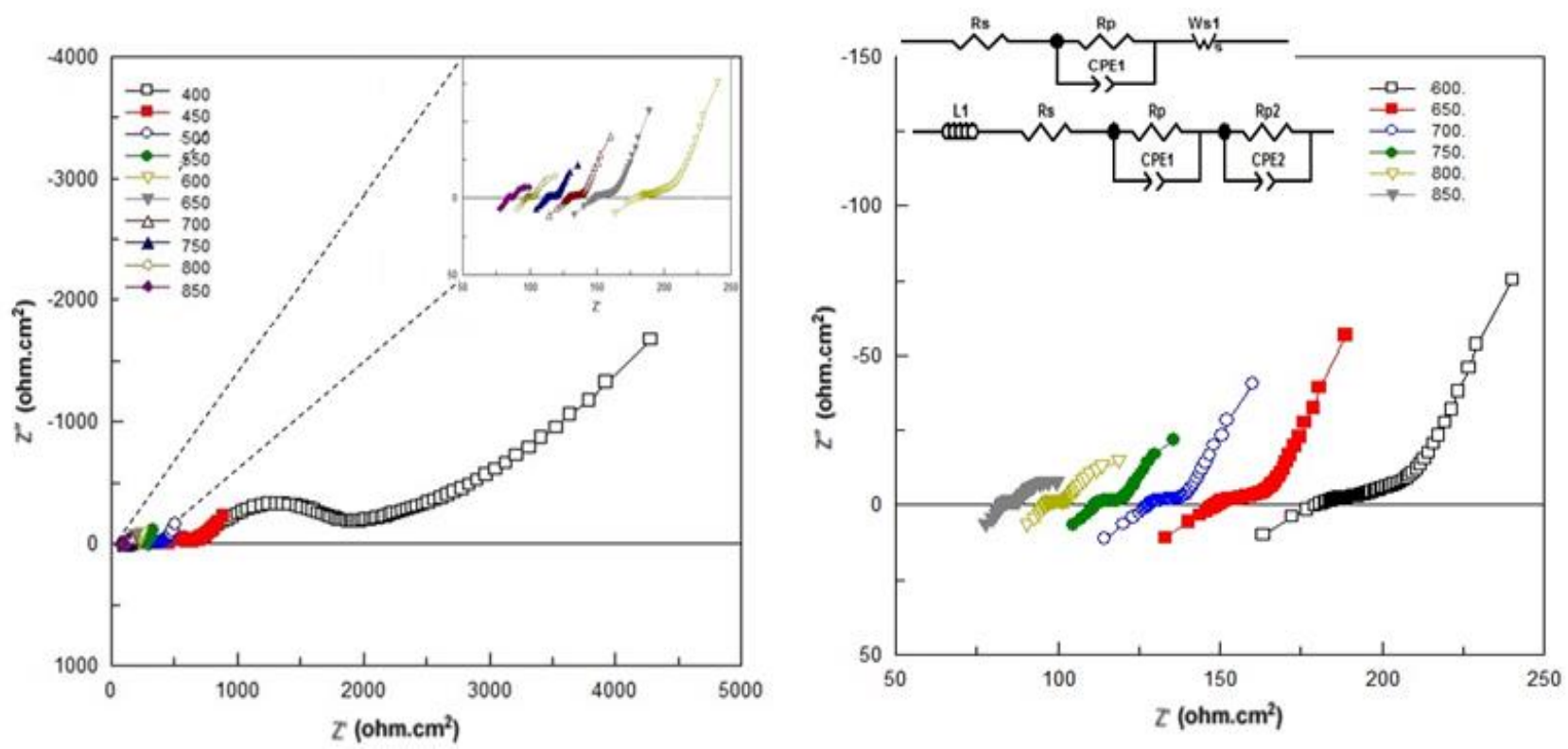

(c)
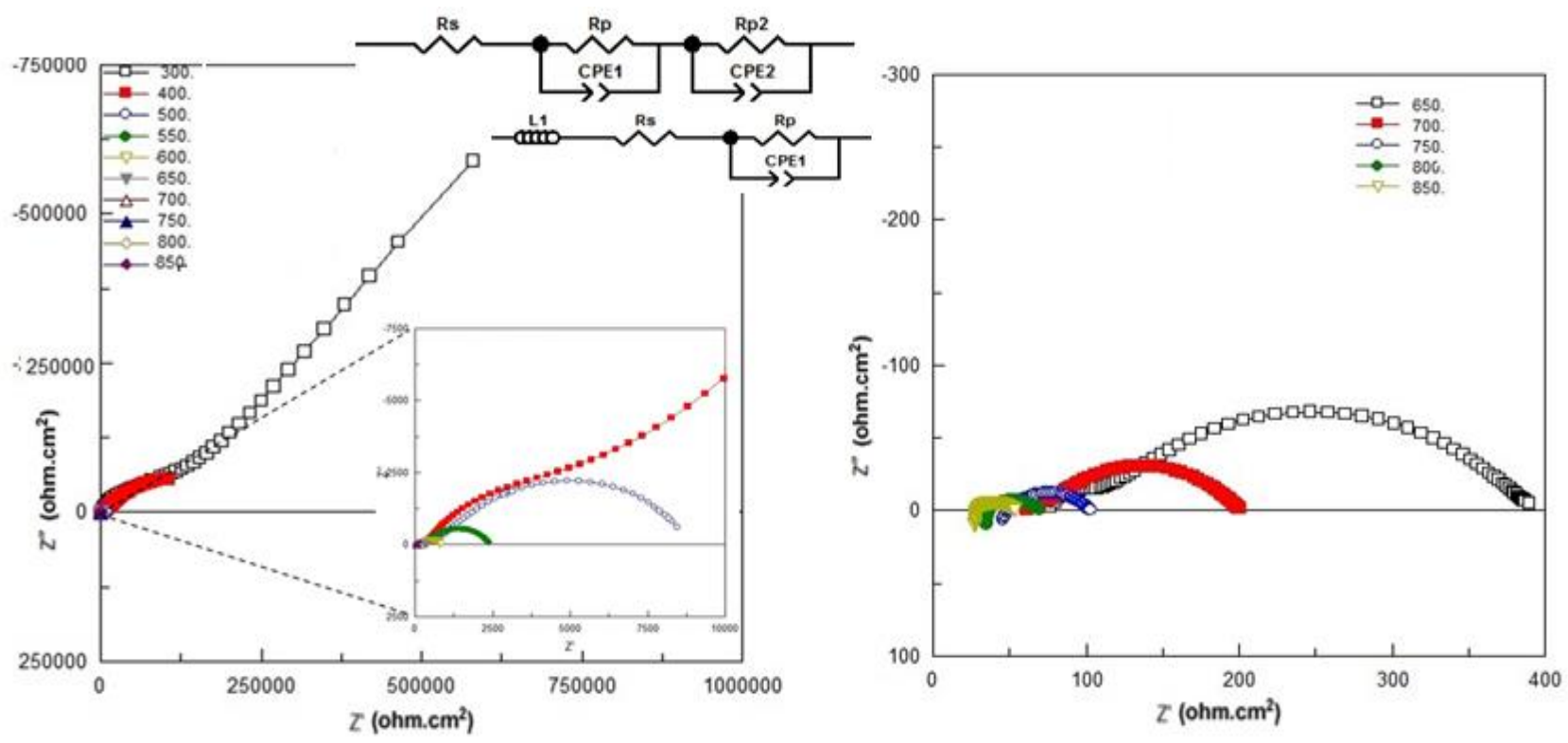

(d) 

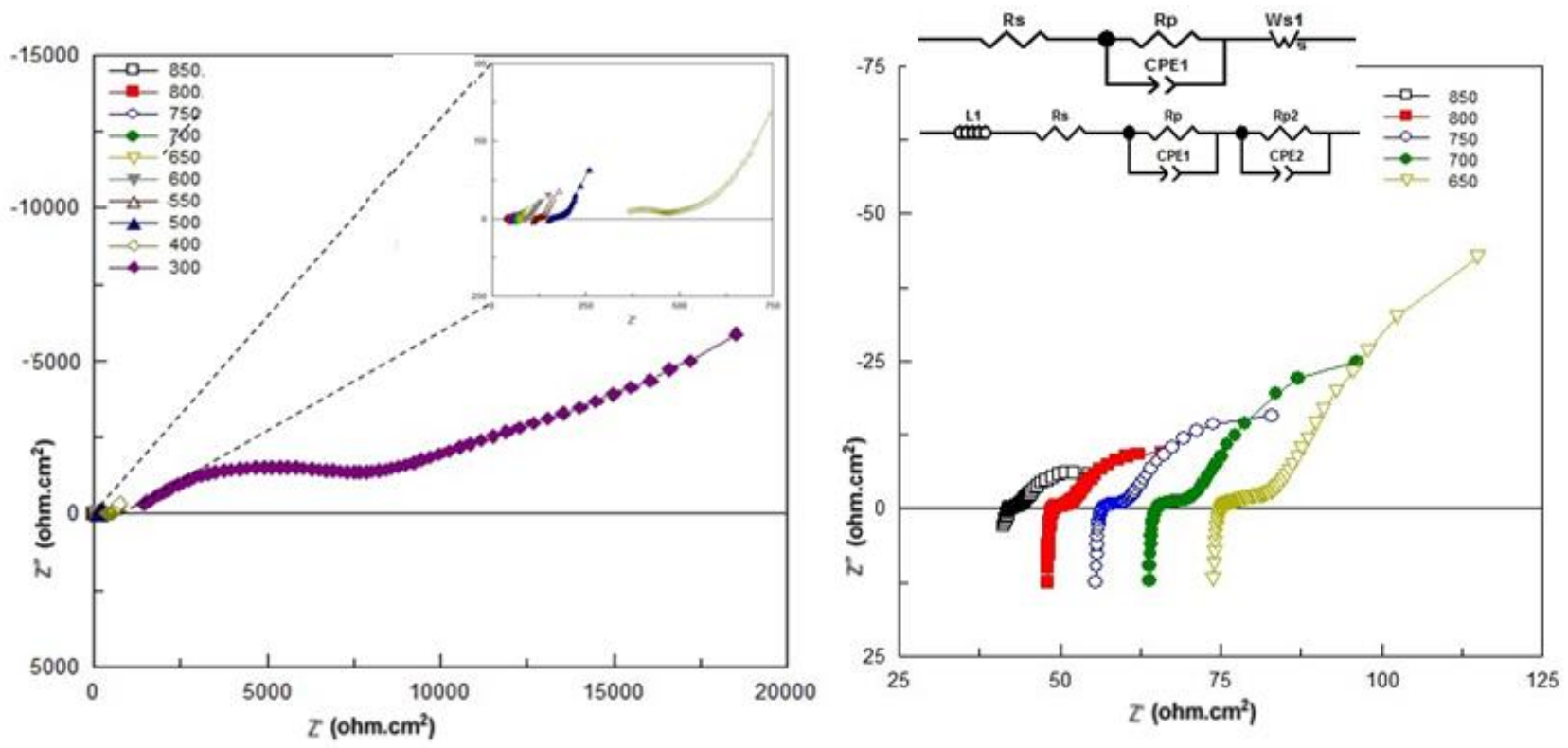

Fig. 5. Nyquist plots of (a) BCZYSZn 2 in air and (b) in wet $5 \% \mathrm{H}_{2}$ atmosphere at temperature range of $400-850{ }^{\circ} \mathrm{C}$; (c) BCZYSZn 3 in air and (d) in wet $5 \% \mathrm{H}_{2}$ atmosphere at temperature range of $300-850{ }^{\circ} \mathrm{C}$; and the right hand side figures are the magnified views for the specific temperatures $\left({ }^{\circ} \mathrm{C}\right)$ shown. The equivalent circuits of EIS analyses are inserted in the figures.

The total conductivities of BCZYSZn 2 and BCZYSZn 3 are in wet $5 \% \mathrm{H}_{2}$ at $600{ }^{\circ} \mathrm{C}$ are $1.23 \times 10^{-}$ ${ }^{3}$ and $2.56 \times 10^{-3} \mathrm{~S} \mathrm{~cm}^{-1}$ and, at $700{ }^{\circ} \mathrm{C}$ are $2.38 \times 10^{-3}$ and $3.89 \times 10^{-3} \mathrm{~S} \mathrm{~cm}^{-1}$, respectively. The samples of BCZYSZn may be therefore used as the electrolyte above $600{ }^{\circ} \mathrm{C}$ if thin film technology is applied.

The Arrhenius plots of the total ionic conductivity of the materials in air compared to wet hydrogen atmosphere in the temperature range of $400-850{ }^{\circ} \mathrm{C}$ are shown in Fig. 6 (a) and (b). It is found that the conductivity increases with increasing in temperature due to thermally activated atoms and transport ions contribution to the conductivity mechanism. In the humidified reducing atmosphere, the conductivity increases compared to that of in air. 
(a)

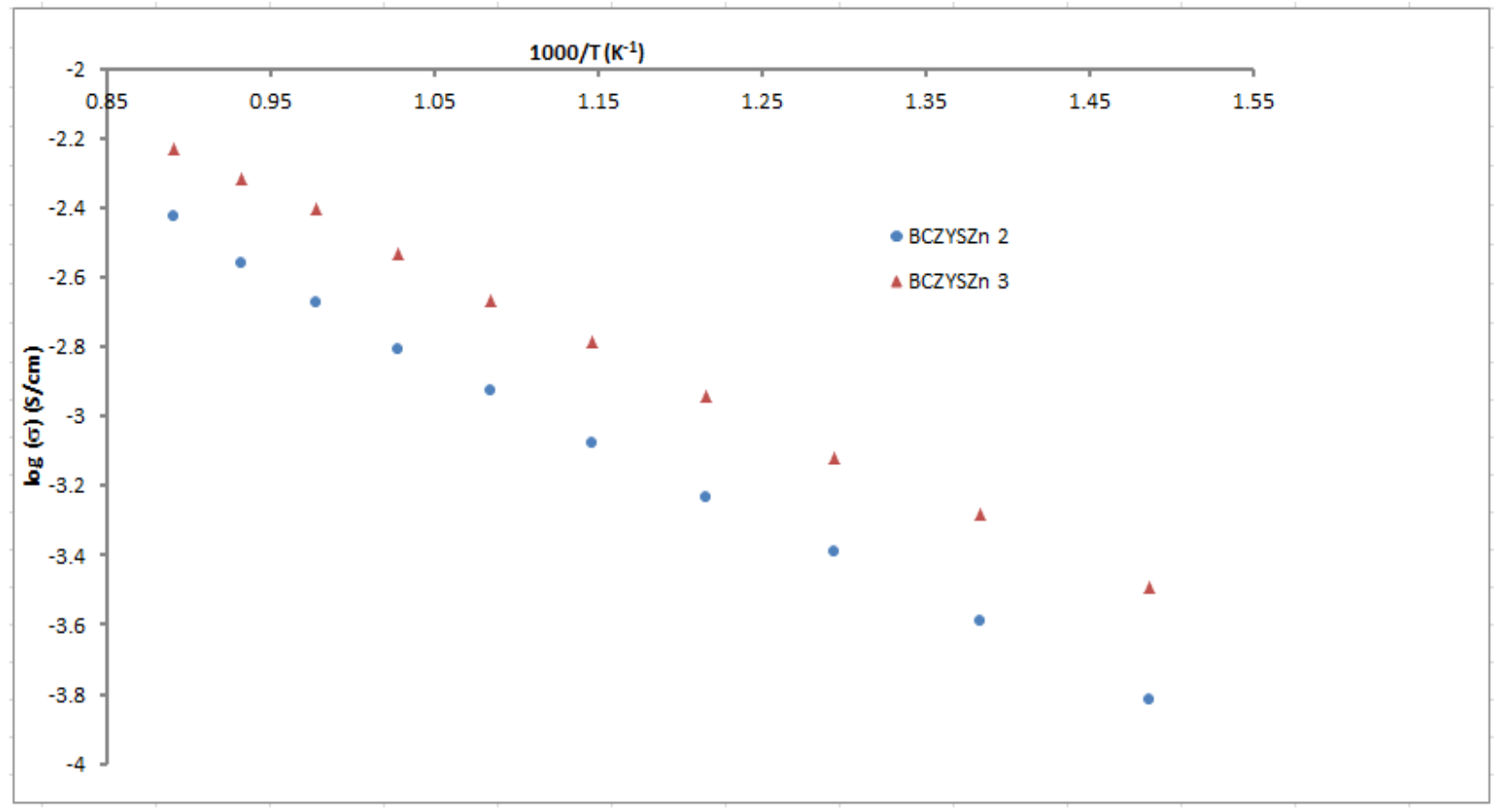

(b)

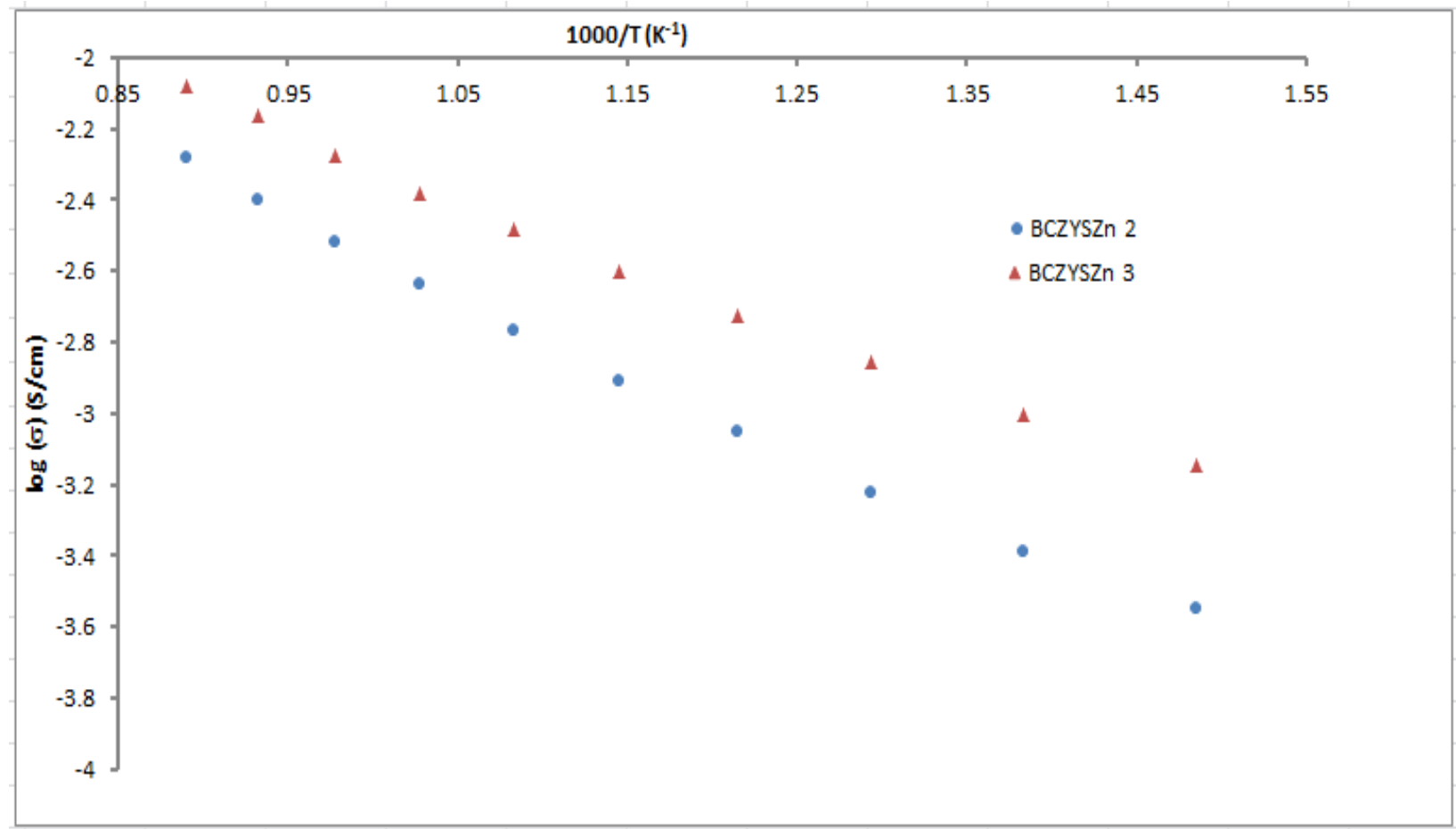


Fig. 6. Arrhenius plots of total conductivity measured in (a) air and (b) wet $5 \% \mathrm{H}_{2}$ at temperature range of $400-850{ }^{\circ} \mathrm{C}$ (the samples names are inserted in the top right).

Table 3 shows the conductivity and activation energy for the compositions of BCZYSZn. As the conductivity in wet $5 \% \mathrm{H}_{2}$ is higher than that of in air, activation energy in wet $5 \% \mathrm{H}_{2}$ is lower compared to that of in air environment due to atoms in compounds perform their ability to conduct ion requiring less activation energy to support. The activation energy performances of BCZYSZn are comparable with $0.39 \mathrm{eV}$ of $\mathrm{BaCe}_{0.8} \mathrm{Y}_{0.2} \mathrm{O}_{3-\delta}$ and lower than $0.61 \mathrm{eV}$ of $\mathrm{BaZr}_{0.8} \mathrm{Y}_{0.2} \mathrm{O}_{3-\delta}[36]$

Table 3. Conductivity and activation energies of BCZYSZn under air and wet $5 \% \mathrm{H}_{2}$ environments.

\begin{tabular}{|c|c|c|c|c|c|c|}
\hline \multirow{3}{*}{$\begin{array}{c}\text { Material } \\
\text { Composition }\end{array}$} & \multicolumn{4}{|c|}{ Conductivity $\left(\mathrm{S} \mathrm{cm}^{-1}\right)$} & \multicolumn{2}{|c|}{ Activation energy (eV) } \\
\hline & \multicolumn{2}{|c|}{$400{ }^{\circ} \mathrm{C}$} & \multicolumn{2}{|c|}{$700{ }^{\circ} \mathrm{C}$} & \multicolumn{2}{|c|}{$400{ }^{\circ} \mathrm{C} \quad 700{ }^{\circ} \mathrm{C}$} \\
\hline & Air & Wet $5 \% \mathrm{H}_{2}$ & Air & Wet $5 \% \mathrm{H}_{2}$ & Air & Wet $5 \% \mathrm{H}_{2}$ \\
\hline BCZYSZn2 & $1.92 \times 10^{-4}$ & $2.95 \times 10^{-4}$ & $1.55 \times 10^{-3}$ & $2.38 \times 10^{-3}$ & 0.4395 & 0.3519 \\
\hline BCZYSZn3 & $4.64 \times 10^{-4}$ & $7.67 \times 10^{-4}$ & $2.73 \times 10^{-3}$ & $3.89 \times 10^{-3}$ & 0.3938 & 0.3243 \\
\hline
\end{tabular}

In proton conducting perovskite, the protons at elevated temperatures are supposed to follow Grotthuss mechanism [61], and transport in the following steps: i) a proton associates with a fixed oxygen atom; ii) under the influence of the neighboring oxygen atoms, the proton oxygen bond reorients; and finally iii) the proton begins to vibrate between the two oxygen atoms and ultimately transfers to the adjacent oxygen. The binding energy between $\mathrm{OH}^{\circ}$ and $\mathrm{M}_{\mathrm{B}^{\prime}}$ varies 
with the dopant. The binding energies simulation results of $\mathrm{OH}^{\circ}-\mathrm{M}_{\mathrm{B}^{\prime}}$ (hydroxyl - dopant pairs at the nearest neighbor sites) for $\mathrm{Y}, \mathrm{Yb}$ and In were $-0.26,-0.35$ and $-0.58 \mathrm{eV}$, respectively which has good agreement with the experimental results. A more stable state for hydroxyl - dopant pair will be found for a more negative value of the binding energies [62].

The conductivity in wet $5 \% \mathrm{H}_{2}$ is higher than in air indicating proton conduction. In general, the well-sintered and highly dense samples of BCZYSZn exhibit much higher conductivity than the less dense materials under the same conditions. The conductivity of the $\mathrm{BaZrO}_{3}$ based proton conducting materials strongly depends on the synthesis and measuring environments. For the electrolyte materials high total conductivity is desired for any practical electrochemical cell. From this point of view, the BCZYSZn 3 exhibits the highest total proton conductivity among the materials studied here.

\subsection{Fuel cell performance}

Single cell performance test was done at $850{ }^{\circ} \mathrm{C}$ to $600{ }^{\circ} \mathrm{C}$ with an interval of $50{ }^{\circ} \mathrm{C}$. The highest power density is obtained at $700{ }^{\circ} \mathrm{C}$ for BCZYSZn 3 electrolyte cell and is shown in Fig. 7 (a). The maximum power density for this electrolyte cell is found to be $0.42 \mathrm{~W} / \mathrm{cm}^{2}$ at $700{ }^{\circ} \mathrm{C}$ and $0.25 \mathrm{~W} / \mathrm{cm}^{2}$ at $850{ }^{\circ} \mathrm{C}$ using air at cathode side and $5 \% \mathrm{H}_{2} / \mathrm{Ar}$ at anode side with the rate of 100 $\mathrm{ml} / \mathrm{S}$. In Fig 7 (a), the open-circuit voltage (OCV) of $1.01 \mathrm{~V}$ at $700{ }^{\circ} \mathrm{C}$ indicates that the electrolyte membrane, prepared by the screen printing process is sufficiently dense. 

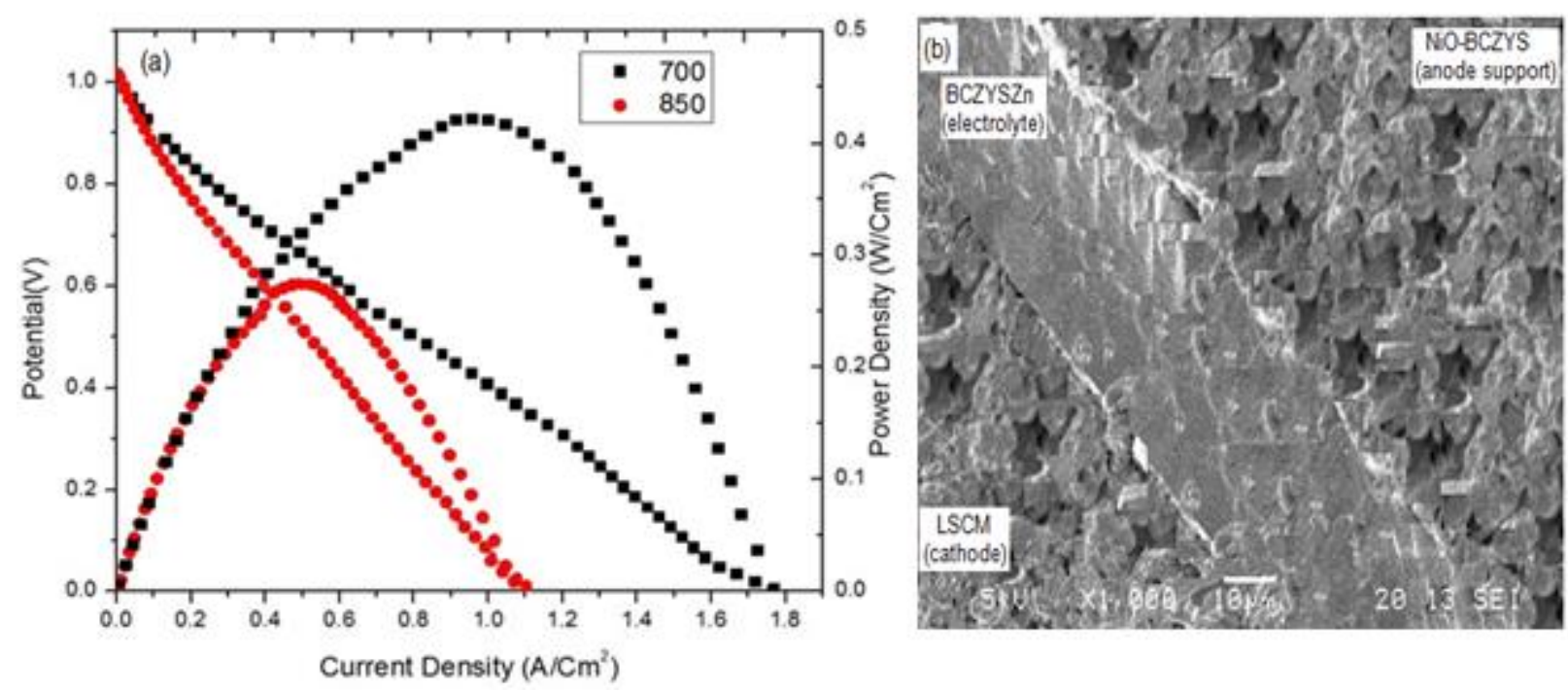

Fig. 7. (a) Current-voltage characteristics and corresponding power densities curves at two different temperatures for the fuel cell with BCZYS 3 anode and BCZYSZn 3 electrolyte; (b) Crosse-sectional image of the single cell.

Fig. 7 (b) shows the cross sectional image of the single cell. In the single cell the electrolyte membrane is found to be highly dense and $39 \mu \mathrm{m}$ thick and cathode layer is found to be around $63 \mu \mathrm{m}$ thick. Although the performance study of BCZYS and BCZYSZn based fuel cell is still not as high as the authors expected, the high chemical stability and large grain morphology of BCZYSZn are very promising and suggest that a different generation of intermediate temperature SOFCs may become conceivable.

\subsection{Chemical stability}

The stability issues of cerium based proton conducting electrolyte materials in $\mathrm{CO}_{2}$ containing atmosphere is the main challenge [17-20]. In $\mathrm{CO}_{2}$ containing atmosphere $\mathrm{BaCeO}_{3}$ reacts with $\mathrm{CO}_{2}$ and forms $\mathrm{BaCO}_{3}$ and $\mathrm{CeO}_{2}$ as shown in Eq. (1), 


$$
\mathrm{BaCeO}_{3}+\mathrm{CO}_{2} \rightarrow \mathrm{BaCO}_{3}+\mathrm{CeO}_{2}
$$

In Eq. (1), the chemical reaction has been reported to occur at $1141{ }^{\circ} \mathrm{C}$ [26]. But our interests for these reporting materials are in applications in intermediate temperature, below the temperature of $1000{ }^{\circ} \mathrm{C}$. So, all the samples of BCZYS and BCZYSZn for comparison were heated up to $1000{ }^{\circ} \mathrm{C}$ in $\mathrm{CO}_{2}$ at $5{ }^{\circ} \mathrm{C} / \mathrm{min}$ from 30 to $1000{ }^{\circ} \mathrm{C}$, held isothermally for $30 \mathrm{~min}$, and then cooled down to $50{ }^{\circ} \mathrm{C}$ at the same rate, with flowing the $\mathrm{CO}_{2}$ gas at a rate of $50 \mathrm{ml} / \mathrm{min}$ for both the carrier and protection gas. In the literatures by many authors $[19,50,58,63,64]$, the heat treatment in $\mathrm{CO}_{2}$ up $1200{ }^{\circ} \mathrm{C}$ or a bit higher has already been reported.

The thermogravimetric analysis (TGA) curves of BCZYS and BCZYSZn are illustrated in Fig. 8 (a). For measuring the chemical stability of the samples the TGA data were collected. The mass of BCZYS 2, BCZYS 3, BCZYSZn 2, and BCZYSZn 3 has been changed by 7.49\%, 7.22\%, $3.22 \%$ and $0.99 \%$, respectively.

The samples of $\mathrm{Zn}$ additive materials were found relatively more stable than without $\mathrm{Zn}$, and no minor peaks in XRD were observed after the TGA experiments as shown in Fig. 8 (b); i.e., the original structure is unaffected.

(a) 


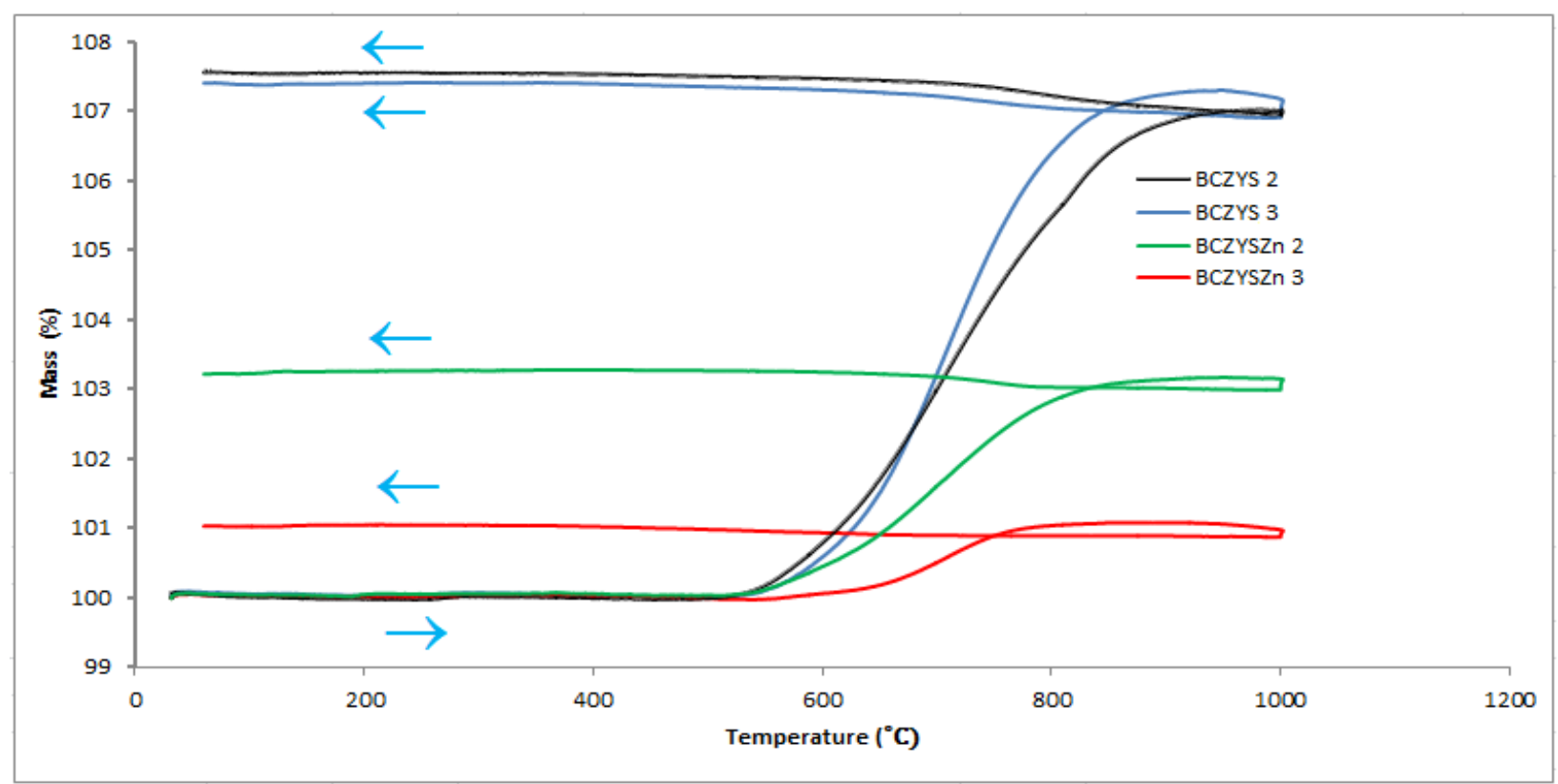

(b)

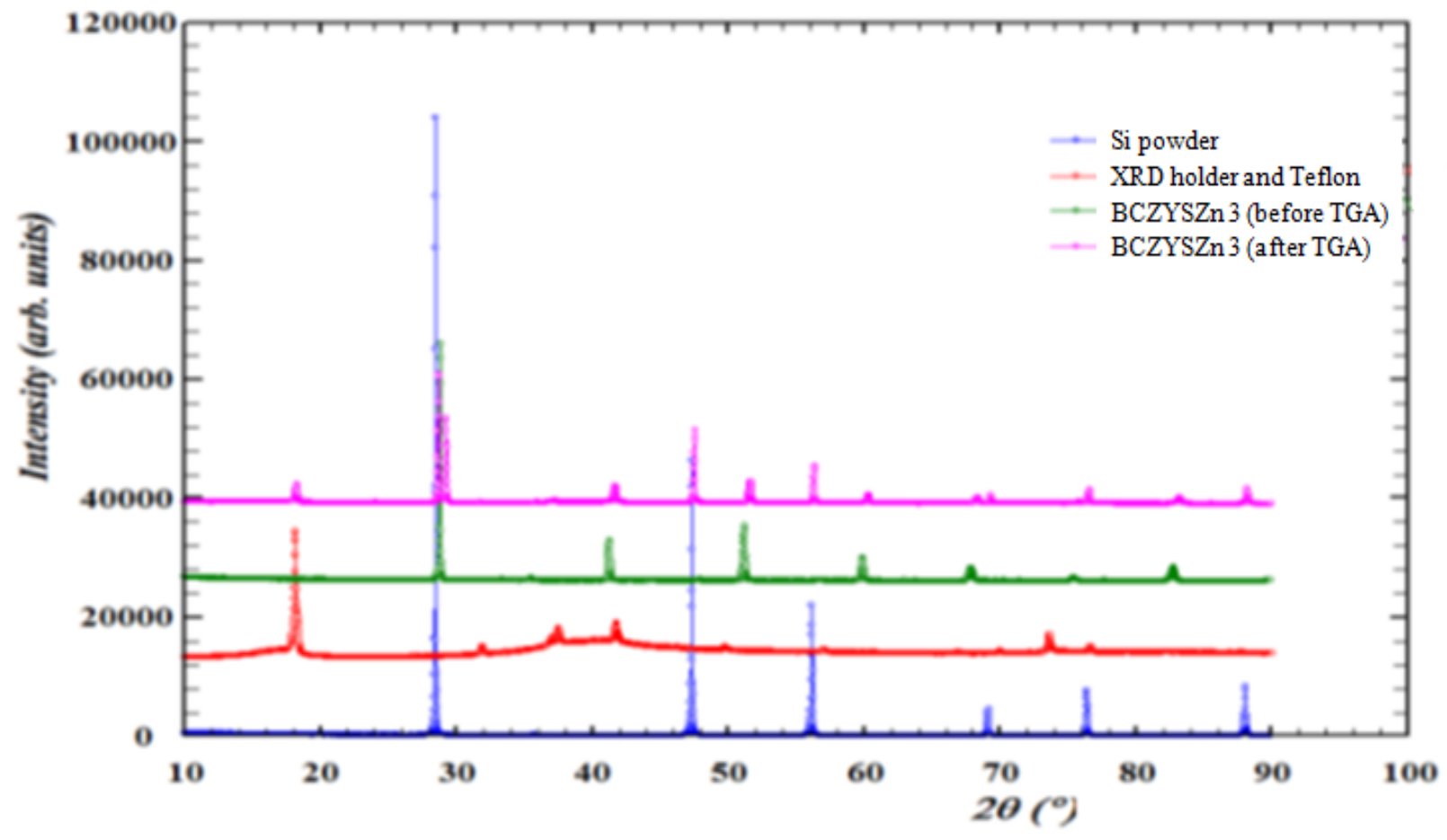


Fig. 8. (a) TGA curves for BCZYS and BCZYSZn with the flowing of pure $\mathrm{CO}_{2}$ gas at a rate of $50 \mathrm{ml} / \mathrm{min}$ for both the carrier and protection and (b) the XRD patterns of BCZYSZn 3 after the TGA experiment.

There is a small weight gain of $\leq 1 \%$ after stability test as can be seen from curve Fig. 8 (a) for the sample BCZYSZn 3 which is much smaller than weight gain of $1.79 \%$ for BZ3C5YYb and $3.22 \%$ for BCZYSZn 2 (which is higher than that of BZ3C5YYb). The weight gain of BCZYSZn 2 and BCZYSZn 3 are higher than the weight gained for a composition with higher $\mathrm{Zr}$ content of $70 \mathrm{~mol} \%$ at the $\mathrm{B}$ site i.e., $\mathrm{BaCe}_{0.2} \mathrm{Zr}_{0.7} \mathrm{Y}_{0.1} \mathrm{O}_{3-\delta}$, which was roughly $0.3-0.4 \%$, when heated in pure $\mathrm{CO}_{2}$ up to $1250{ }^{\circ} \mathrm{C}$ with a heating and cooling rate of $2^{\circ} \mathrm{C} / \mathrm{min}$ [58]. For the material with $30 \mathrm{~mol} \%$ of $\mathrm{Zr}$ at the $\mathrm{B}$ site; i.e., $\mathrm{BaC}_{0.6} \mathrm{Zr}_{0.3} \mathrm{Y}_{0.1} \mathrm{O}_{3-\delta}$, the weight gain was about $2 \%$ under the same conditions [58]. In case of BZCYYb, the weight gain was 7.7\%, when heated to $1200{ }^{\circ} \mathrm{C}$ in pure $\mathrm{CO}_{2}$ with a heating and cooling rate of $10{ }^{\circ} \mathrm{C} / \mathrm{min}$. Similarly, the weight gain was $>9 \%$ for $\mathrm{BaCe}_{0.5} \mathrm{Zr}_{0.3} \mathrm{Y}_{0.2} \mathrm{O}_{3-\delta}$ when heated up to $1200{ }^{\circ} \mathrm{C}$ with a heating/cooling rate of 5 ${ }^{\circ} \mathrm{C} / \min [50]$.

Fig. 8 (b) shows the XRD patterns of BCZYSZn 3 after the TGA experiment with other added materials as the small amounts of samples used for thermogravimetrical analysis, each sample was mixed with silicon standard powder in a Teflon lined XRD holder. The XRD peaks after the TGA in $\mathrm{CO}_{2}$ environment show the same pattern i.e., no extra or impurity peak was detected.

Hence, no extra peak corresponding to $\mathrm{CeO}_{2}$ for the samples of BCZYS and BCZYSZn have been seen, it is quite stable. A proton conducting electrolyte material heating below the carbonation say up to $800{ }^{\circ} \mathrm{C}$ in $\mathrm{CO}_{2}$ is not a good representative for testing its chemical stability and for this reason some well-known materials, like BZCY and BZCYYb proton conducting 
electrolyte materials were initially reported to be stable in $\mathrm{CO}_{2}$, but later found to be unstable when tested at higher temperatures [31-33,35,37]. Hence, the chemical stability test in $\mathrm{CO}_{2}$ up to $1000{ }^{\circ} \mathrm{C}$ is vital for intermediate temperature IT-SOFCs. Nevertheless, for practical applications the relative density and stability is still quite high.

\section{Conclusions}

The $\mathrm{BaCeO}_{3}-\mathrm{BaZrO}_{3}$ based samarium, yttrium doped novel materials of $\mathrm{BCZYS}$ adding 4 wt. \% $\mathrm{ZnO}$ as sintering aid have been successfully prepared at $1350{ }^{\circ} \mathrm{C}$. This temperature is lower than the required sintering temperature of $1700{ }^{\circ} \mathrm{C}$ without additive. The relative density and stability of the materials are also quite high. It is observed in the formation of single phase material that samarium doped and $\mathrm{ZnO}$ addition significantly improves the density and stability where $\mathrm{Zn}$ expected to occupy the B-site of the perovskite on forming a solid solution. All samples were single phase orthorhombic structure with space group Pbnm. The conductivity of the dense and well sintered sample was much higher than the lower density samples. In general, the conductivity in wet $5 \% \mathrm{H}_{2}$ is higher than that in air indicating proton conduction. The total conductivities of BCZYSZn 2 and BCZYSZn 3 are in wet $5 \% \mathrm{H}_{2}$ are $1.23 \times 10^{-3}$ and $2.56 \times 10^{-3} \mathrm{~S}$ $\mathrm{cm}^{-1}$ at $600{ }^{\circ} \mathrm{C}$. The maximum power density for BCZYSZn 3 electrolyte cell is found to be 0.42 $\mathrm{W} / \mathrm{cm}^{2}$ at $700{ }^{\circ} \mathrm{C}$. The proton conductivity and power density values, together with the large grain, low temperature sinterability and good stability in $\mathrm{CO}_{2}$ make the material suitable for practical application in IT-SOFC.

\section{Acknowledgements}


S. Hossain and A. M. Abdalla are thankful to graduate studies office of Universiti Brunei Darussalam for graduate research scholarship (GRS) for this research work done. Authors are also grateful to Professor John T. S. Irvine for managing a visiting scholarship for SH and AMA to perform the research work at University of St Andrews, Scotland, UK.

\section{References}

[1] Souza ECC De, Muccillo R. Properties and applications of perovskite proton conductors. Mater Res 2010;13:385-94. doi:10.1590/S1516-14392010000300018.

[2] Haugsrud R, Norby T. Proton conduction in rare-earth ortho-niobates and ortho-tantalates. Nat Mater 2006;5:193-6. doi:10.1038/nmat1591.

[3] Fabbri E, Pergolesi D, Traversa E. Materials challenges toward proton conducting oxide fuel cells: a critical review. Chem Soc Rev 2010;39:4355-69. doi:10.1039/B902343G.

[4] Duan C, Tong J, Shang M, Nikodemski S, Sanders M, Ricote S, et al. Readily processed protonic ceramic fuel cells with high performance at low temperatures. Sci 2015;349:1321-6. doi:10.1126/science.aab3987.

[5] Hossain S, Abdalla AM, Jamain SNB, Zaini JH, Azad AK. A review on proton conducting electrolytes for clean energy and intermediate temperature-solid oxide fuel cells. Renew Sustain Energy Rev 2017;79:750-64. doi:10.1016/j.rser.2017.05.147.

[6] Radenahmad N, Afif A, Petra PI, Rahman SMH, Eriksson S-G, Azad AK. Protonconducting electrolytes for direct methanol and direct urea fuel cells - A state-of-the-art review. Renew Sustain Energy Rev 2016;57:1347-58. doi:10.1016/j.rser.2015.12.103.

[7] Kreuer KD. Proton-Conducting Oxides. Annu Rev Mater Res 2003;33:333-59. doi:10.1146/annurev.matsci.33.022802.091825.

[8] Shi Z, Sun W, Liu W. Synthesis and characterization of $\mathrm{BaZr}_{0.3} \mathrm{Ce}_{0.5} \mathrm{Y}_{0.2-\mathrm{x}} \mathrm{Yb}_{\mathrm{x}} \mathrm{O}_{3-\delta}$ proton 
conductor for solid oxide fuel cells. J Power Sources 2014;245:953-7. doi:10.1016/j.jpowsour.2013.07.060.

[9] Fabbri E, Pergolesi D, Traversa E. Electrode materials: a challenge for the exploitation of protonic solid oxide fuel cells. Sci Technol Adv Mater 2010;11:044301. doi:10.1088/1468-6996/11/4/044301.

[10] Bonano N, Ellis B, Mahmood MN. Construction and operation of fuel cells based on the solid electrolyte $\mathrm{BaCeO}_{3}$ :Gd. Solid State Ionics 1991;44:305-11. doi:10.1016/01672738(91)90023-5 .

[11] Ma GL, Shimura T, Iwahara H. Ionic conduction and nonstoichiometry in $\mathrm{Ba}_{\mathrm{x}} \mathrm{Ce}_{0.90} \mathrm{Y}_{0.10} \mathrm{O}_{3-\delta} . \quad$ Solid State Ionics 1998;110:103-10. doi:10.1016/S01672738(98)00130-1.

[12] Schober T, Bohn HG. Water vapor solubility and electrochemical characterization of the high temperature proton conductor $\mathrm{BaZr}_{0.9} \mathrm{Y}_{0.1} \mathrm{O}_{2.95}$. Solid State Ionics 2000;127:351-60. doi:10.1016/S0167-2738(99)00283-0.

[13] Kreuer KD, Adams S, Münch W, Fuchs A, Klock U, Maier J. Proton conducting alkaline earth zirconates and titanates for high drain electrochemical applications. Solid State Ionics, 2001;145:295-306. doi:10.1016/S0167-2738(01)00953-5.

[14] Iguchi F, Sata N, Tsurui T, Yugami H. Microstructures and grain boundary conductivity of $\mathrm{BaZr}_{1-\mathrm{x}} \mathrm{Y}_{\mathrm{x}} \mathrm{O}_{3}(\mathrm{x}=0.05,0.10,0.15)$ ceramics. Solid State Ionics 2007;178:691-5. doi:10.1016/j.ssi.2007.02.019.

[15] D’Epifanio A, Fabbri E, Di Bartolomeo E, Licoccia S, Traversa E. Design of $\mathrm{BaZr}_{0.8} \mathrm{Y}_{0.2} \mathrm{O}_{3-\delta}$ protonic conductor to improve the electrochemical performance in intermediate temperature solid oxide fuel cells (IT-SOFCs). Fuel Cells 2008;8:69-76. 
doi:10.1002/fuce.200700045.

[16] Ricote S, Caboche G, Heintz O. Synthesis and proton incorporation in $\mathrm{BaCe}_{0.9-\mathrm{x}} \mathrm{Zr}_{\mathrm{x}} \mathrm{Y}_{0.1} \mathrm{O}_{3-\delta}$. J Appl Electrochem 2009;39:553-7. doi:10.1007/s10800-008-97456.

[17] Scholten MJ, Schoonman J, van Miltenburg JC, Oonk HAJ. Synthesis of strontium and barium cerate and their reaction with carbon dioxide. Solid State Ionics 1993;61:83-91. doi:10.1016/0167-2738(93)90338-4.

[18] Chen FL, Sorensen OT, Meng GY, Peng DK. Chemical stability study of $\mathrm{BaCe}_{0.9} \mathrm{Nd}_{0.1} \mathrm{O}_{3-\delta}$ high-temperature proton-conducting ceramic. J Mater Chem 1997;7:481-5. doi:10.1039/a605377g.

[19] Taniguchi N, Nishimura C, Kato J. Endurance against moisture for protonic conductors of perovskite-type ceramics and preparation of practical conductors. Solid State Ionics, 2001;145:349-55. doi:10.1016/S0167-2738(01)00930-4.

[20] Khan MN, Savaniu CD, Azad AK, Hing P, Irvine JTS. Wet chemical synthesis and characterisation of $\mathrm{Ba}_{0.5} \mathrm{Sr}_{0.5} \mathrm{Ce}_{0.6} \mathrm{Zr}_{0.2} \mathrm{Gd}_{0.1} \mathrm{Y}_{0.1} \mathrm{O}_{3-\delta}$ proton conductor. Solid State Ionics 2017;303:52-7. doi:http://dx.doi.org/10.1016/j.ssi.2017.01.001.

[21] Snijkers FMM, Buekenhoudt A, Cooymans J, Luyten JJ. Proton conductivity and phase composition in $\quad \mathrm{BaZr}_{0.9} \mathrm{Y}_{0.1} \mathrm{O}_{3-\delta}$. Scr $\quad$ Mater 2004;50:655-9. doi:10.1016/j.scriptamat.2003.11.028.

[22] Yamazaki Y, Hernandez-Sanchez R, Haile SM. High total proton conductivity in largegrained yttrium-doped barium zirconate. Chem Mater 2009;21:2755-62. doi:10.1021/cm900208w.

[23] Katahira K, Kohchi Y, Shimura T, Iwahara H. Protonic conduction in Zr-substituted 
$\mathrm{BaCeO}_{3}$. Solid State Ionics 2000;138:91-8. doi:http://dx.doi.org/10.1016/S01672738(00)00777-3.

[24] Haile SM, Staneff G, Ryu KH. Non-stoichiometry, grain boundary transport and chemical stability of proton conducting perovskites. J Mater Sci 2001;36:1149-60. doi:10.1023/A:1004877708871.

[25] Azad AK, Irvine JTS. Synthesis, chemical stability and proton conductivity of the perovksites $\quad \mathrm{Ba}(\mathrm{Ce}, \mathrm{Zr})_{1-\mathrm{x}} \mathrm{Sc}_{\mathrm{x}} \mathrm{O}_{3-\delta} . \quad$ Solid State Ionics 2007;178:635-40. doi:10.1016/j.ssi.2007.02.004.

[26] Azad AK, Irvine JTS. High density and low temperature sintered proton conductor $\mathrm{BaCe}_{0.5} \mathrm{Zr}_{0.35} \mathrm{Sc}_{0.1} \mathrm{Zn}_{0.05} \mathrm{O}_{3-\delta} . \quad$ Solid State Ionics 2008;179:678-82. doi:DOI 10.1016/j.ssi.2008.04.036.

[27] Osman N, Talib IA, Hamid HA. Effect of zirconium substitution on the phase formation and microstructure of $\mathrm{BaCeO}_{3}$. Sains Malaysiana 2010;39:479-84.

[28] Wang L, Guo H, Xiao S, Han J, Lü J. Structure, chemical stability, and electrochemical properties of $\mathrm{Ba}\left(\mathrm{Ce}_{0.5} \mathrm{Zr}_{0.5}\right)_{1-\mathrm{x}} \mathrm{Y}_{\mathrm{x}} \mathrm{O}_{3-\delta}$. Ionics (Kiel) 2011;18:899-906. doi:10.1007/s11581012-0693-0.

[29] Sawant P, Varma S, Wani BN, Bharadwaj SR. Synthesis, stability and conductivity of $\mathrm{BaCe}_{0.8-\mathrm{x}} \mathrm{Zr}_{\mathrm{x}} \mathrm{Y}_{0.2} \mathrm{O}_{3-\delta}$ as electrolyte for proton conducting SOFC. Int J Hydrogen Energy 2012;37:3848-56. doi:10.1016/j.ijhydene.2011.04.106.

[30] Lin Y, Ran R, Guo Y, Zhou W, Cai R, Wang J, et al. Proton-conducting fuel cells operating on hydrogen, ammonia and hydrazine at intermediate temperatures. Int $\mathbf{J}$ Hydrogen Energy 2010;35:2637-42. doi:10.1016/j.ijhydene.2009.04.019.

[31] Zuo C, Zha S, Liu M, Hatano M, Uchiyama M. $\mathrm{Ba}\left(\mathrm{Zr}_{0.1} \mathrm{Ce}_{0.7} \mathrm{Y}_{0.2}\right) \mathrm{O}_{3-\delta}$ as an Electrolyte for 
Low-Temperature Solid-Oxide Fuel Cells. Adv Mater 2006;18:3318-20. doi:10.1002/adma.200601366.

[32] Bi L, Tao Z, Liu C, Sun W, Wang H, Liu W. Fabrication and characterization of easily sintered and stable anode-supported proton-conducting membranes. J Memb Sci 2009;336:1-6. doi:10.1016/j.memsci.2009.03.042.

[33] Yang L, Wang S, Blinn K, Liu M, Liu Z, Cheng Z, et al. Enhanced sulfur and coking tolerance of a mixed ion conductor for SOFCs: $\left.\mathrm{BaZr}_{(0.1)} \mathrm{Ce}_{(0.7)} \mathrm{Y}_{(0.2-\mathrm{x})} \mathrm{Yb}_{(\mathrm{x})} \mathrm{O}_{(3-\delta)}\right)$. Science 2009;326:126-9. doi:10.1126/science.1174811.

[34] Zhou X, Liu L, Zhen J, Zhu S, Li B, Sun K, et al. Ionic conductivity, sintering and thermal expansion behaviors of mixed ion conductor $\mathrm{BaZr}_{0.1} \mathrm{Ce}_{0.7} \mathrm{Y}_{0.1} \mathrm{Yb}_{0.1} \mathrm{O}_{3-\delta}$ prepared by ethylene diamine tetraacetic acid assisted glycine nitrate process. J Power Sources 2011;196:5000-6. doi:10.1016/j.jpowsour.2011.01.092.

[35] Mirfakhraei B, Ramezanipour F, Paulson S, Birss V, Thangadurai V. Effect of sintering temperature on microstructure, chemical stability, and electrical properties of transition metal or Yb-doped BaZrO ${ }_{3}$ Front Energy Res 2014;2:1-10. doi:10.3389/fenrg.2014.00009.

[36] Fabbri E, D’Epifanio A, Di Bartolomeo E, Licoccia S, Traversa E. Tailoring the chemical stability of $\mathrm{Ba}\left(\mathrm{Ce}_{0.8-\mathrm{x}} \mathrm{Zr}_{\mathrm{x}}\right) \mathrm{Y}_{0.2} \mathrm{O}_{3-\delta}$ protonic conductors for Intermediate Temperature Solid Oxide Fuel Cells (IT-SOFCs). Solid State Ionics 2008;179:558-64. doi:10.1016/j.ssi.2008.04.002.

[37] Kannan R, Singh K, Gill S, Fürstenhaupt T, Thangadurai V. Chemically stable proton conducting doped $\mathrm{BaCeO}_{3}$-no more fear to SOFC wastes. Sci Rep 2013;3:2138. doi:10.1038/srep02138.

[38] Iwahara H, Uchida H, Morimoto K. High Temperature Solid Electrolyte Fuel Cells Using 
Perovskite-Type Oxide Based on $\mathrm{BaCeO}_{3}$ Anode. J Electrochem Soc 1990;137:462-5.

[39] Wang JX, Su WH, Xu DP, He TM. Electrical properties of solid solutions $\mathrm{Ba}_{1.1} \mathrm{Ce}_{1-}$ ${ }_{\mathrm{x}} \mathrm{Eu}_{\mathrm{x}} \mathrm{O}_{3-\delta} . \mathrm{J}$ Alloys Compd 2006;421:45-8. doi:DOI 10.1016/j.jallcom.2005.11.028.

[40] Iwahara H, Yajima T, Hibino T, Ozaki K, Suzuki H. Protonic conduction in calcium, strontium and barium zirconates. Solid State Ionics 1993;61:65-9. doi:10.1016/01672738(93)90335-Z.

[41] Bonanos N. Transport properties and conduction mechanism in high-temperature protonic conductors. Solid State Ionics 1992;53-56:967-74. doi:10.1016/0167-2738(92)90278-W.

[42] Bohn HG, Schober T. Electrical conductivity of the high-temperature proton conductor $\mathrm{BaZr}_{0.9} \mathrm{Y}_{0.1} \mathrm{O}_{2.95 .} . \quad \mathrm{J} \quad$ Am $\quad$ Ceram $\quad$ Soc $2000 ; 83: 768-72 . \quad$ doi:10.1111/j.11512916.2000.tb01272.x.

[43] Azad AK, Savaniu C, Tao S, Duval S, Holtappels P, Ibberson RM, et al. Structural origins of the differing grain conductivity values in $\mathrm{BaZr}_{0.9} \mathrm{Y}_{0.1} \mathrm{O}_{2.95}$ and indication of novel approach to counter defect association. J Mater Chem 2008;18:3414. doi: 10.1039/b806190d.

[44] Wang H, Peng R, Wu X, Hu J, Xia C. Sintering behavior and conductivity study of yttrium-doped $\mathrm{BaCeO}_{3}-\mathrm{BaZrO}_{3}$ solid solutions using $\mathrm{ZnO}$ additives. J Am Ceram Soc 2009;92:2623-9. doi:10.1111/j.1551-2916.2009.03204.x.

[45] Liou YC, Tseng KH, Chung TC. Effect of dopants on synthesis of $\mathrm{BaTi}_{4} \mathrm{O}_{9}$ and $\mathrm{Ba}_{2} \mathrm{Ti}$ ${ }_{9} \mathrm{O}_{20}$ ceramics prepared by reaction-sintering process. J Eur Ceram Soc 2007;27:3027-32. doi:10.1016/j.jeurceramsoc.2006.11.039.

[46] Gorbova E, Maragou V, Medvedev D, Demin A, Tsiakaras P. Influence of sintering additives of transition metals on the properties of gadolinium-doped barium cerate. Solid 
State Ionics 2008;179:887-90. doi:10.1016/j.ssi.2008.02.065.

[47] Khan MN, Azad AK, Savaniu CD, Hing P, Irvine JTS. Robust doped $\mathrm{BaCeO}_{3-\delta}$ electrolyte for IT-SOFCs. Ionics (Kiel) 2017;23:2387-96. doi:DOI 10.1007/s11581-017-2086-x.

[48] Babilo P, Haile SM. Enhanced sintering of yttrium-doped barium zirconate by addition of ZnO. J Am Ceram Soc 2005;88:2362-8. doi:10.1111/j.1551-2916.2005.00449.x.

[49] Lin B, Hu M, Ma J, Jiang Y, Tao S, Meng G. Stable, easily sintered $\mathrm{BaCe}_{0.5} \mathrm{Zr}_{0.3} \mathrm{Y}_{0.16} \mathrm{Zn}_{0.04} \mathrm{O}_{3-\delta}$ electrolyte-based protonic ceramic membrane fuel cells with $\mathrm{Ba}_{0.5} \mathrm{Sr}_{0.5} \mathrm{Zn}_{0.2} \mathrm{Fe}_{0.8} \mathrm{O}_{3-\delta}$ perovskite cathode. J Power Sources 2008;183:479-84. doi:10.1016/j.jpowsour.2008.05.075.

[50] Tao S, Irvine JTS. A stable, easily sintered proton-conducting oxide electrolyte for moderate-temperature fuel cells and electrolyzers. Adv Mater 2006;18:1581-4.doi: 10.1002/adma.200502098.

[51] Tao S, Irvine JTS. Conductivity studies of dense yttrium-doped $\mathrm{BaZrO}_{3}$ sintered at $1325^{\circ}$ C. J Solid State Chem 2007;180:3493-503. doi:10.1016/j.jssc.2007.09.027.

[52] Zhang CJ, Zhao HL, Xu NS, Li X, Chen N. Influence of ZnO addition on the properties of high temperature proton conductor $\mathrm{Ba}_{1.03} \mathrm{Ce}_{0.5} \mathrm{Zr}_{0.4} \mathrm{Y}_{0.1} \mathrm{O}_{3-\delta}$ synthesized via citrate-nitrate method. Int J Hydrogen Energy 2009;34:2739-46. doi:DOI 10.1016/j.ijhydene.2009.01.061.

[53] Lu X, Ding Y, Chen Y. $\mathrm{Ba}_{0.5} \mathrm{Sr}_{0.5} \mathrm{Zn}_{0.2} \mathrm{Fe}_{0.8} \mathrm{O}_{3-\delta}-\mathrm{BaCe}_{0.5} \mathrm{Zr}_{0.3} \mathrm{Y}_{0.16} \mathrm{Zn}_{0.04} \mathrm{O}_{3-\delta}$ composite cathode for proton-conducting solid oxide fuel cells. J Alloys Compd 2009;484:856-9. doi:10.1016/j.jallcom.2009.05.065.

[54] Afif A, Radenahmad N, Lim CM, Petra MI, Islam MA, Rahman SMH, et al. Structural study and proton conductivity in $\mathrm{BaCe}_{0.7} \mathrm{Zr}_{0.25-\mathrm{x}} \mathrm{Y}_{\mathrm{x}} \mathrm{Zn}_{0.05} \mathrm{O}_{3}(\mathrm{x}=0.05,0.1,0.15,0.2$ \&amp; 
0.25). Int J Hydrogen Energy 2016;41:11823-31. doi:http://dx.doi.org/10.1016/j.ijhydene.2016.02.135.

[55] Yang K, Wang JX, Xue YJ, Wang M Sen, He CR, Wang Q, et al. Synthesis, sintering behavior and electrical properties of $\mathrm{Ba}\left(\mathrm{Zr}_{0.1} \mathrm{Ce}_{0.7} \mathrm{Y}_{0.2}\right) \mathrm{O}_{3-\delta}$ and $\mathrm{Ba}\left(\mathrm{Zr}_{0.1} \mathrm{Ce}_{0.7} \mathrm{Y}_{0.1} \mathrm{Yb}_{0.1}\right) \mathrm{O}_{3-\delta}$ proton conductors. Ceram Int 2014;40:15073-81. doi:10.1016/j.ceramint.2014.06.115.

[56] Yang L, Zuo C, Liu M. High-performance anode-supported Solid Oxide Fuel Cells based on $\mathrm{Ba}\left(\mathrm{Zr}_{0.1} \mathrm{Ce}_{0.7} \mathrm{Y}_{0.2}\right) \mathrm{O}_{3-\delta}$ (BZCY) fabricated by a modified co-pressing process. J Power Sources 2010;195:1845-8. doi:10.1016/j.jpowsour.2009.10.018.

[57] Wang S, Zhao F, Zhang L, Chen F. Synthesis of $\mathrm{BaCe}_{0.7} \mathrm{Zr}_{0.1} \mathrm{Y}_{0.1} \mathrm{Yb}_{0.1} \mathrm{O}_{3-\delta}$ proton conducting ceramic by a modified Pechini method. Solid State Ionics 2012;213:29-35. doi:10.1016/j.ssi.2011.05.014.

[58] Ricote S, Bonanos N, Caboche G. Water vapour solubility and conductivity study of the proton conductor $\mathrm{BaCe}_{(0.9-\mathrm{x})} \mathrm{Zr}_{\mathrm{x}} \mathrm{Y}_{0.1} \mathrm{O}_{(3-\delta)}$. Solid State Ionics 2009;180:990-7. doi:10.1016/j.ssi.2009.03.016.

[59] Azad AK, Kruth A, Irvine JTS. Influence of atmosphere on redox structure of $\mathrm{BaCe}_{0.9} \mathrm{Y}$ ${ }_{0.1} \mathrm{O}_{2.95}$-Insight from neutron diffraction study. Int J Hydrogen Energy 2014;39:12804-11. doi:10.1016/j.ijhydene.2014.05.080.

[60] Wang W, Virkar A V. Ionic and electron-hole conduction in $\mathrm{BaZr}_{0.93} \mathrm{Y}_{0.07} \mathrm{O}_{3-\delta}$ by 4-probe dc measurements. J Power Sources 2005;142:1-9. doi:10.1016/j.jpowsour.2004.09.031.

[61] Agmon N. The Grotthuss mechanism. Chem Phys Lett 1995;244:456-62. doi:10.1016/0009-2614(95)00905-J.

[62] Azad AK, Irvine JTS. Location of Deuterium Positions in the Proton-Conducting Perovskite $\mathrm{BaCe}_{0.4} \mathrm{Zr}_{0.4} \mathrm{Sc}_{0.2} \mathrm{O}_{2.90} \times \mathrm{xD}_{2} \mathrm{O}$ by Neutron Powder Diffraction. Chem Mater 
2009;21:215-22. doi:10.1021/cm8031847.

[63] Fabbri E, Bi L, Tanaka H, Pergolesi D, Traversa E. Chemically stable Pr and Y Co-doped barium zirconate electrolytes with high proton conductivity for intermediate-temperature solid oxide fuel cells. Adv Funct Mater 2011;21:158-66. doi:10.1002/adfm.201001540.

[64] Barison S, Battagliarin M, Cavallin T, Doubova L, Fabrizio M, Mortalò C, et al. High conductivity and chemical stability of $\mathrm{BaCe}_{1-\mathrm{x}-\mathrm{y}} \mathrm{Zr}_{\mathrm{x}} \mathrm{Y}_{\mathrm{y}} \mathrm{O}_{3-\delta}$ proton conductors prepared by a sol-gel method. J Mater Chem 2008;18:5120-8. doi:10.1039/b808344d. 